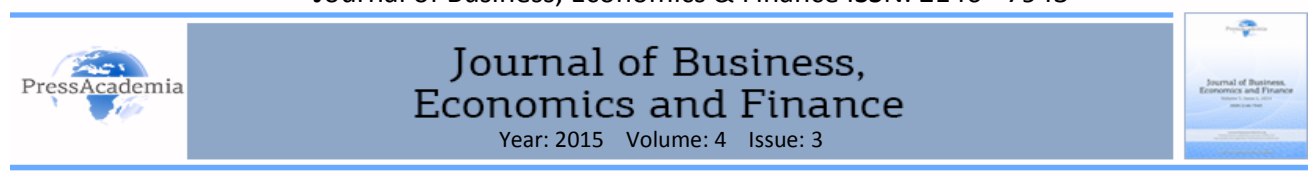

\title{
BANK COMPETITION, CONCENTRATION AND RISK-TAKING IN THE TURKISH BANKING INDUSTRY
}

\section{DOI: 10.17261/Pressacademia.2015313139}

\section{Gülin Vardar ${ }^{1}$}

${ }^{1}$ Izmir University of Economics, E-mail: gulin.karasulu@ieu.edu.tr

\section{Keywords}

Bank competition, financial stability, banking system fragility, bank regulation, Turkey.

\section{JEL Classification} G21, G28

\begin{abstract}
This paper addresses the impacts of bank competition on the risk-taking behaviors of banks in Turkey over the period 2002-2012. After estimating $\mathrm{H}$ statistic as a measure of competition and regressing this measure and other explanatory variables on the bank risk indicators, this paper concludes that competition has a negative impact on the financial fragility of Turkish banks, indicating that banks in a more competitive market tend to take lower level of risk. This finding supports the arguments of the "competition-stability" hypothesis in the Turkish banking system. Furthermore, bank concentration is found to be inversely related to bank risk. On the one hand, bank size, lending, liquidity, off-balance sheet activities are essential factors in explaining this relationship. On the other hand, a few instrumental variables are employed to reflect the country's overall macroeconomic condition. In general, despite the negative impact of interest rate on bank risk-taking behavior in most of the models, in which different risk measures are used as dependent variables, the result highlights the empirical evidence of no significant association between economic growth and bank risk-taking. Overall, this paper aims to provide policy implications for bank management and consolidation policies and also the role of the Central Bank.
\end{abstract}

\section{INTRODUCTION}

Through the liberalization of capital flows, and increasing globalization trend in the world financial system since 1980s, banking competition has been a topic of great concern for both researchers and policy makers. As a result of the liberalization process, banking markets were stimulated by foreign bank entry, merger and consolidation activities, and other type of restructuring reforms, thereby, fostering competition. A more competitive environment is expected to create more efficiency in the banking system in terms of lowering prices, and producing higher quality financial products (Boyd and Nicolo, 2005). However, the impact of competition on the stability of the banking sector remains an open question. There are two main contradictory theories explaining this issue, namely, "competition-fragility" and "competition-stability". Based on the some empirical studies, increased competition leads to greater banking risk-taking, and thereby, greater fragility in the banking sector (Chan, Greenbaum and Thakor, 1986; Furlong and Keeley, 1989; and Keeley, 1990; Carletti, 2005; Vives, 2010; Allen and Gale, 2000, 2004; Cordella and Yeyati, 2002). In contrast, other studies support that more competition results in greater, rather than less stability, and also that the frequency of crises is reduced in more competitive 
banking markets (Boyd and De Nicolo, 2005; Beck et al., 2006). With the increasing deregulation and consolidation process, and also significant structural changes, especially in the developing countries, this paper aims to investigate empirically whether competition has any effect on bank risk-taking, and thereby, the financial stability of the banking sector in Turkey over the period 2002-2011. Our interest is to determine whether either "competition-fragility" or "competition-stability" theory explains the Turkish banking market, or whether both are simultaneously valid. This study focuses on Turkish banking market for several reasons. First, Turkish banking system has undergone dramatic changes from the financial liberalization process in 1980s to the severe 2000 and 2001 financial crises. Following the crisis period, some rehabilitation and restructuring programs were conducted to provide a more competitive, efficient and stable banking environment. Moreover, through the intensive regulation process after 2000s, the number of banks, employees and branches declined, resulting in a change in the competitive structure of the banking environment. Second, since the financial system in Turkey is dominated by the banking sector providing higher source of financing to private and public sectors, the stability of banking system remains an important issue for both academicians and policy makers.

In order to investigate the impact of competition on bank risk-taking, this paper employs four different risk indicators as dependent variables; loan loss provision over total loans, and loans under follow-up over total loans are used as risk indicators to account for loan risk, whereas volatility of ROA and Z-index are used to measure the overall bank risk. Competition is measured by the well-known Panzar-Rose's approach, which constructs $\mathrm{H}$ statistics. In addition to competition, one of the main goals of this paper is to investigate whether the bank concentration has any effect on bank risk-taking behaviors of Turkish banks, and also the financial stability of the banking system over the period 2002-2011.

On the whole, this paper also enables us to examine the impact of important factors, such as size, liquidity, lending, interest rate, off-balance sheet items, on the relationship between bank competition and risk-taking. The contribution of this paper to the literature is two-fold: First, to the author's best knowledge, this is one of the pioneering studies that measure both the impact of competition on the financial stability of the banking system by including a wider perspective of risk and competition measures, in addition to some explanatory variables. This study uses both static - fixed effects and random effectsmodels and dynamic models. Second, it considers the 2002-2011 period, characterized as the restructuring period of Turkish banking market after 2000 and 2001 Turkish financial crises and also the recent global financial crises.

The rest of the paper is structured as follows: Section 2 provides a brief theoretical and empirical literature on the link between bank competition and financial stability. Section 3 describes the data, variables and provides descriptive statistics. Section 4 highlights the methodology used in this paper. Section 5 discusses empirical results and the final section concludes the paper.

\section{LITERATURE REVIEW}

There is an extensive theoretical and empirical literature exploring the relationship between competition and risk in banking. This literature review firstly discusses the 
theoretical framework, and then focuses on the empirical literature on competition and bank-risk taking.

\subsection{Theoretical Literature}

Two main hypotheses have been proposed in the existing banking literature: the 'competition-fragility' hypothesis and the 'competition-stability' hypothesis. 'Competitionstability' hypothesis, which is also called as 'franchise value paradigm', states that increased competition among banks leads to greater banking risk-taking and thereby, greater financial fragility. This is because intense bank competition results in a reduction in market power as well as profit margin, which especially weakens the franchise value of banks ${ }^{1}$. Therefore, in order to cover the losses from the decline in the franchise value, banks will have greater incentives to take on more risks for profits. Initiated by Marcus (1984), one of the earliest studies in this literature, this view is theoretically modeled by Chan, Greenbaum and Thakor (1986), Furlong and Keeley (1989), and Keeley (1990). Using a state preference model with two periods, Furlong and Keeley (1989) and Keeley (1990) indicate that a decline in franchise value increases bank risk-taking. Furthermore, as in the study of Chan, Greenbaum and Thakor (1986), increased competition erodes the informational rents that the banks earn through their relationship with borrowers. This leads banks to decrease their incentives to screen potential borrowers, thereby, the credit quality of banks declines. As a general view of this hypothesis, deregulation which results in more bank entry and competition, leads to greater fragility. Consistent with the competition-fragility literature, Besanko and Thakor (1993) show that increased competition leads banks to take greater risk because of eroding the informational rents initiated from relationship banking activities. Marquez (2002) demonstrate in a framework of asymmetric information that more competition with an increase in the number of banks in a market results in dispersion in the borrower-specific information, therefore, implying a higher funding rates and greater access to credit for low-quality borrowers.

In a framework of imperfect competition, Matutes and Vives $(1996,2000)$ showed that if the market power of a bank increases, its default probability declines. Likewise, Hellman, Murdock and Stiglitz (2000) assert that more competition with lower bank margins can have a negative impact on prudent behavior of banks, thereby, resulting in more risktaking. In order to overcome the enormous gambling incentives in the system, they suggested that deposit rate controls, as well as capital requirements, should be included into the regulatory instruments. These results are consistent with the findings of Repullo (2004), who found that in the absence of regulation, banks will take on greater levels of risk in a more competitive environment. Thus, risk-shifting incentives should be effectively monitored by risk-adjusted capital requirements. There are also many studies in the theoretical literature that support the view that increased competition leads to greater risk-taking, and thereby, greater financial fragility (Carletti, 2005; Vives, 2010; Allen and Gale, 2000, 2004; Cordella and Yeyati, 2002; Caminal and Matutes, 2002; Saez and Shi, 2004).

Although most previous theoretical literature above support the competition-fragility hypothesis under the assumption of competition in the deposit side of the bank balance sheet, the competition-stability hypothesis of Boyd and De Nicolo (BDN, 2005) assumes competition in both loan and deposit sides of the market. Focusing on the deposit side of 
the balance sheet, it is assumed that banks can earn higher rents since they pay lower deposit rates in less competitive markets. However, in a moral hazard environment, as in Stiglitz and Weiss (1981), on the lending side of the market, banks can charge higher interest rates to borrowers in a less competitive market. The higher borrowing rates may enhance the risk-taking behavior of banks and thus, leading to an increase in the default risk of banks, and as well, a systemic crisis ${ }^{2}$. This view, which is also called as 'risk shifting' paradigm, generally suggests that higher levels of competition results in more, rather than less stability (Boyd and De Nicolo, 2005). More recently, Martinez-Miera and Repullo (MMR, 2010) extend the BDN model by introducing imperfect correlation across borrowing firms' default probabilities. As in the BDN model, their model also covers "riskshifting effect", in the sense that more competition leads to lower loan rates, lower default and bankruptcy risk and lower risk-taking by banks. However, because their model allows for imperfect correlation across firms, it suggests the existence of "margin effect", which supports that lower loan rates decrease the overall bank revenues, and therefore, this would probably lead to greater bank risk-taking and bank failures. Thus, the resulting net effect between bank competition and financial stability is not clear, since these two effects work in opposite directions. Specifically, based on MMR model, the margin effect is shown to dominate the risk-shifting effect in more competitive markets, implying that more competition in a market increases bank risk-taking, and thus, results in greater financial fragility. On the other hand, the risk shifting effect is shown to dominate the margin effect in a more concentrated banking market, suggesting that increased competition leads to lower bank risk-taking and bank failure risk. Generally, in the MMR model, there is a U-shaped relationship between bank competition, measured by the number of banks, and bank failure risk.

\subsection{Empirical Literature}

The link between bank competition and bank risk-taking has become the subject of lively debate among academicians throughout the world over the last three decades. The empirical evidence, however, about this relationship is somewhat mixed and inconclusive. Using Tobin's $q$ as a measure of degree of bank competition, Keeley (1990) was the first who found that after the financial deregulation in the US, competition in the banking industry caused a reduction in bank risk during the 1980s, which is in support of the franchise value hypothesis. In a single country setting, Demsetz, Saidenberg and Strahan (1996) show that the banks with a higher market power have higher solvency ratios and a lower level of bank risk. Using again a sample of US banking industry, Saunders and Wilson (1996), and Brewer and Saidenberg (1996), consistent results with Keeley's study (1990), find a negative relationship between franchise value and bank risk. Hellman et al. (2000) analyze the Japanese banking industry and find that increased competition in the banking environment after the financial liberalization process during 1990s results in a reduction in profitability and franchise value of domestic banks. As a result, this led to the East Asian crisis and deterioration in the Japanese banking system. In terms of country-specific literature review, for Spain, Salas and Saurina (2003) provides the empirical evidence of significant and robust relationship between bank competition and bank risk-taking, replicating the study of Keeley (1990), while Bofondi and Gobbi (2004) highlight that the increase in the number of banks in Italian banking industry deteriorates the default loan rates. Jayaratne and Strahan (1998) find that after the relaxation of branching statewide, 
loan loss provisions decline in a sharp manner, thereby, decreasing bank risk. Overall, increased competition has the opposite effect of franchise value paradigm. However, Dick (2006) finds a positive and significant relationship between banking deregulation and increases in loan losses. Jimenez, Lopez and Saurina (2008) provide empirical evidence for a negative relationship between bank competition, measured as Lerner index, and risktaking in Spanish banks. Fungacova and Weill (2009) show that an increase in bank competition is specifically associated with greater bank failures in the case of Russian banks. In addition to bank competition and risk taking relationship, the analysis of whether the reduction in the franchise value through the liberalization periods is associated with banking crisis or not is empirically studied in the previous literature (Stiglitz and Weiss (1981), Taylor (1983), Cho (1986), Fry (1988), Dornbush and Reynoso (1989), Jensen (1989) and Chan and Velasco (2001). Besides the above-mentioned studies in single-country settings, using $\mathrm{H}$-statistics as a measure of bank competition, Levy-Yeyati and Micco (2007) analyze eight Latin American countries' banks and show that increased bank competition leads to increase in bank risk, supporting the "competition-fragility" hypothesis. Using a sample of developing countries over the period 1999-2005, Ariss (2010) reveals that even though greater bank market power leads to greater bank risk, and also stimulates the profit efficiency, the cost efficiency of banks will deteriorate.

Although there is an extensive literature supporting "franchise value" hypothesis, Boyd, De Nicolo and Jalal (2006) provide cross-country empirical evidence that supports "competition-stability" hypothesis. Using several bank measures for a US and international bank sample, they find a negative and significant relationship between bank competition, measured as Herfindahl and Hirschmann index ( $\mathrm{HHI}$ ), and bank risk-taking, namely $z$-score, suggesting that banks are exposed to greater risk of failures in more concentrated/less competitive banking environments. Additionally, taking bank ownership into consideration, De Nicolo and Loukoianova (2007) find empirical evidence on competition-stability hypothesis. In a cross-country setting, Uhde and Heimeshoff (2009) test the bank concentration effect on financial stability of European Union countries over the period 1997-2005, and conclude that market concentration has a negative effect on the financial soundness of European banks. Particularly interesting is the finding that this negative bank concentration effect is found to be more severe in the less developed countries of Eastern Europe. Using a sample of 38 countries between 1980 and 2003, Schaeck, Cihak, and Wolfe (2006) find that greater bank competition is associated with less systemic risk. In the case of eight Latin American countries, Yeyati and Micco (2007) find consistent result with the previous literature on "competition-stability". They show a negative link between bank competition and risk-taking of banks, implying that greater competition leads banks to take on less risk. Liu, Molyneux and Nguyen (2012) investigate the effects of competition on the banks of Southeast Asia, and conclude that competition does not necessarily increase bank risk-taking. Based on the analysis of 8235 banks in 23 developed countries, Berger, Klapper and Turk-Ariss (2009) shed light on both "competition-fragility" hypothesis and "competition-stability" hypothesis. Their results show that banks with a higher degree of market power have lower overall risk measures, which supports the "competition-fragility" hypothesis. However, their analysis provides evidence that supports the "competition-stability" hypothesis, indicating that greater bank market power results in an increase in non-performing loans. This risk is partially offset by higher capital ratios. Based on the analysis of Asian banking industry during the 2001-2007 period, 
by considering a sample of broader set of Asian banks over the period 1994-2009, Soedarmono, Machrou and Tarazi (2013) show that the banks with higher degree of market power have correspondingly higher capital ratios, higher income volatility and higher insolvency risk. However, through the crisis period, higher market power is associated with lower bank risk-taking and insolvency risk. In a single-country setting, Jimenez, Lopez and Saurina (2013) examine the relationship between bank competition and risk-taking within the context of the Spanish banking system. The results support the original franchise value only in the loan market whereas the overall results provide empirical evidence on MMR model.

The relationship between bank competition and bank risk taking has been investigated in many studies, either on single-country or cross-country settings, across a range of developed and developing countries. However, little research has been conducted specifically on Turkey, which is one of the biggest economies in Eastern Europe and Middle East, and has extensively reformed and restructured its banking system after the severe 2001 crisis. Based on the analysis of Turkish banking system over the period 19882007, Tunay (2009) provides evidence in favor of the "competition-stability" hypothesis for Turkey. In line with the findings of Tunay (2009), Yaldız and Bazzana (2010) examine the link between market power and bank risk-taking in Turkey for the period of 2001-2009, finding some empirical evidence to the support the "competition-stability" hypothesis. On the other hand, the results provide insufficient evidence for the impact of market power on the risk-taking behavior of Turkish banks after the year 2000.

\section{DATA}

Bank level data for all banks operating in Turkey for the period 2002-2011 were obtained from the "Banks Association of Turkey". Since the period 1999-2001 can be considered as the years of crisis and the consequent transformation and restructuring, the sample period represents the period after severe economic and banking crisis in order to eliminate the impacts of these crises on the Turkish Banking System. The final sample covers annual information for a balanced panel of 280 bank-level observations covering 28 banks ${ }^{3}$. Of these, 3 are state-owned banks, 11 are privately-owned, 9 are foreign banks founded in Turkey, and 5 are foreign banks with branches in Turkey. 


\section{Table 1: List of Deposit Banks Used in the Study}

\begin{tabular}{|l|l|}
\hline State-Owned Deposit Banks & Foreign Banks Founded in Turkey \\
\hline Türkiye Cumhuriyeti Ziraat Bankası A.Ş. & Alternatifbank A.Ş. \\
\hline Türkiye Halk Bankası A.Ş. & Arap Türk Bankası A.Ş. \\
\hline Türkiye Vakıflar Bankası T.A.O. & Citibank A.Ş. \\
\hline & Denizbank A.Ş. \\
\hline Privately-Owned Deposit Banks & Deutsche Bank A.Ş. \\
\hline Adabank A.Ş. & Finans Bank A.Ş. \\
\hline Akbank T.A.Ş. & HSBC Bank A.Ş. \\
\hline Anadolubank A.Ş. & ING Bank A.Ş. \\
\hline Fibabanka A.Ş. & Turkland Bank A.Ş. \\
\hline Şekerbank T.A.Ş. & \\
\hline Tekstil Bankası A.Ş. & Foreign Banks having branches in Turkey \\
\hline Turkish Bank A.Ş. & Bank Mellat \\
\hline Türk Ekonomi Bankası A.Ş. & Habib Bank Limited \\
\hline Türkiye Garanti Bankası A.Ş. & JPMorgan Chase Bank N.A. \\
\hline Türkiye İş Bankası A.Ş. & Société Générale (SA) \\
\hline Yapı ve Kredi Bankası A.Ş. & The Royal Bank of Scotland Plc. \\
\hline
\end{tabular}

In order to investigate the impact of competition on risk taking behaviors of banks in Turkey, different measures of competition and bank-risk taking are used. Table 2 shows the names and descriptions of the variables used in the models. As a proxy of risk-taking, four different accounting measures ${ }^{4}$ as dependent variables are employed in the study. First, ratio of loan-loss provisions over total loans (LLPTL), which reflects the expense for banks to account for future losses on loan defaults, is used as a measure of credit risk. A second credit risk measure is non-performing loans ratio, measured as the ratio of loans under follow up over total loans (LUFTL). In general, when loan-loss provisions and loans under follow up increase, this suggests that banks are exposed to much more risk. Even if credit risk is the primary driver of risk for most banks, banks face a number of risks to conduct their business. Third, the volatility of ROA is employed in the study as a risk component to reflect market risk. Finally, the evolution of overall bank risk is measured by Z-index, which is calculated as the ratio of the sum of ROA and equity-to-asset ratio over the volatility of ROA. Z-index has been commonly used in many studies in the banking literature to measure "safety and soundness" of a banking sector (Nash and Sinkey, 1997; De Nicolo, 2000; De Nicolo, Bartholomew, Zaman and Zephirin 2004; Boyd, De Nicolo and Jalal, 2006; Yeyati and Micco, 2007; Uhde and Heimeshoff, 2009; Yaldız and Bazzana, 2010; Liu, Molyneux \& Nguyen, 2012; Liu and Wilson, 2012; Tabak, Fazio and Cajueiro, 2012) since it combines profitability, leverage and return volatility in one single measure (Berger et al., 2008). Z-index is positively related with the profitability and capitalization, but negatively related with unstable returns proxied by the higher standard deviation of ROA; thus, higher values of Z-index indicate lower level of overall bank risk. 
As discussed previously, various measures of degree of bank concentration have been used in the literature. Three standard measures are used in our analysis, namely, Concentration 3 (C3 hereafter), Concentration 5 (C5, hereafter) ratios and HerfindahlHirschman Index ( $\mathrm{HHI}$ ). C3 and C5 ratios represent the concentration ratios of the biggest 3 and 5 banks with respect to the share of their assets of the banking sector. Although relatively easy to calculate, these ratios do not include the information about the remaining banks in the banking sector. Therefore, to eliminate this limitation, HerfindahlHirschman Index (HHI) is used as an additional measure of degree of bank concentration. Risk-taking behavior of banks can clearly be affected by a number of bank specific and macroeconomic factors, not all of which are included in the bank competition measure. As a proxy for macroeconomic factors, therefore, real interest lending rate and economic growth are used to control for the changes in the economic environment.

Table 2: Variables Used in the Study

\begin{tabular}{lll}
\hline Variables & \multicolumn{2}{c}{ Description } \\
\hline & Loans under follow-up / Total Loans & LUF/TL \\
\cline { 2 - 3 } & Loan-loss provisions / Total Loans & LLP/TL \\
\cline { 2 - 3 } & $\begin{array}{l}\text { Deviation of individual bank's return on asset } \\
\text { (ROA) from the sample mean within one period }\end{array}$ & $\begin{array}{l}\text { ROA } \\
\text { volatility }\end{array}$ \\
\cline { 2 - 3 } Bank Risk Indicators & $\begin{array}{l}\text { Logarithm of Z-index (Z-index is defined as the ratio } \\
\text { of the sum of ROA and equity-to-asset ratio over } \\
\text { the volatility of ROA) }\end{array}$ & \\
& & LNZ-index
\end{tabular}

\begin{tabular}{lll}
\hline Size & Natural Logarithm of Total Assets & LNTA \\
\hline Liquidity & Liquid Assets / Total Deposits & LA/TD \\
\hline Off-Balance & Off-Balance Sheet Items / Total Assets & OBS/TA \\
\hline Lending & Total Loans / Total Assets & TL/TA \\
\hline Interest Rate & Real Interest Lending Rate & i \\
\hline Economic growth & Logarithm of growth in Gross Domestic Product & LNGDF \\
\hline Concentration Indices & & C3 \\
\hline Concentration - 3 & $\begin{array}{l}\text { Ratio of three largest bank's } \\
\text { over total banking sector assets }\end{array}$ & C5 \\
\hline Concentration - 5 & $\begin{array}{l}\text { Ratio of five largest bank's assets over total } \\
\text { banking sector assets }\end{array}$ & HHI- \\
\hline $\begin{array}{l}\text { Herfindahl-Hirschman } \\
\text { Index for Assets }\end{array}$ & $\begin{array}{l}\text { Sum of squared market shares (measured in } \\
\text { fractions of the total bank assets) of all banks in the } \\
\text { industry }\end{array}$ & Assets \\
\hline
\end{tabular}


The study considers the use of certain bank-level explanatory variables, such as size, liquidity, off-balance sheet items, and lending, in order to determine whether they have an impact of banking sector risk. Table 3 presents the descriptive statistics for the variables used in the study.

From this table, the average LUFTL ratio is $19.8 \%$ with a large degree of dispersion across banks, ranging from $0 \%$ to $27 \%$. A similar outcome holds for the LLPTL ratio, with an average of $14 \%$ and a large dispersion from $0 \%$ to $37 \%$. ROA volatility has an average of $0.4 \%$, however, the dispersion is not as wide as the other risk measures. For the latest measure, Z-index does not display a wide variation for Turkish banks over time $(-0.29$ to 9.62). The market share of the first three and five commercial banks, denoted as C3 and $\mathrm{C5}$, has an average of $42.1 \%$ and $61.5 \%$, and the value $\mathrm{HHI}$ for assets does not exceed 1000 , indicating that the Turkish banking sector could be described as almost non-concentrated over the period 2002-2012. The average annual value of TLTA ratio is $41.9 \%$, with a high degree of variation, ranging from $0 \%$ to above $84 \%$. Additionally, as evidence of bank size, the natural logarithm of banks' total assets ranges from 9.71 to 18.40 , thus reflecting a widely dispersed distribution of this variable.

Table 3: Descriptive Statistics

\begin{tabular}{lccccc}
\hline Variables & Mean & Median & Std. Dev. & Maximum & Minimum \\
\hline LUF/TL & 0.198 & 0.024 & 2.336 & 37.591 & 0.000 \\
\hline LLP/TL & 0.140 & 0.017 & 1.737 & 27.970 & 0.004 \\
\hline ROA volatility & 0.004 & 0.002 & 0.009 & 0.117 & 0.000 \\
\hline LNZ-index & 4.550 & 4.379 & 1.309 & 9.627 & -0.290 \\
\hline LNTA & 14.733 & 14.679 & 2.115 & 18.404 & 9.718 \\
\hline LA/TD & 17.619 & 0.584 & 35.282 & 281.490 & 0.083 \\
\hline OBS/TA & 2.989 & 1.906 & 3.273 & 27.602 & 0.018 \\
\hline TL/TA & 0.419 & 0.440 & 0.203 & 0.847 & 0.003 \\
\hline I & 25.088 & 22.256 & 11.864 & 53.879 & 14.186 \\
\hline LNGDPG & 4.657 & 4.665 & 0.041 & 4.695 & 4.556 \\
\hline C3 & 0.421 & 0.422 & 0.015 & 0.456 & 0.404 \\
\hline C5 & 0.615 & 0.619 & 0.015 & 0.630 & 0.584 \\
\hline HHI-Assets & 0.095 & 0.095 & 0.003 & 0.099 & 0.088 \\
\hline
\end{tabular}

Note: LUFTL is the ratio of loans under follow-up over total loans. LLPTL is the ratio of loan-loss provisions over total loans. ROA volatility is the deviation of individual bank's return on asset (ROA) from the sample mean within one period. Z-index is the ratio of the sum of ROA and equity-to-asset ratio over the volatility of ROA. LNTA is the natural logarithm of total asset of bank as a measure of bank size; LA/TD is the ratio of liquid asset over total deposit as a measure of liquidity; $T L / T A$ is the ratio of total loan over total asset of bank as a measure of lending; OBS/TA is the ratio of off-balance sheet items over total assets as a measure of off-balance sheet activity; i represents real interest lending rate in Turkish economy; LNGDPG represents the natural logarithm of real GDP growth rate of Turkish economy; C3 denotes the share of the 3 largest banks in the country; C5 denotes the share of the 5 largest banks; $\mathrm{HHI}$-assets is the Herfindahl Index of concentration based on total assets. 
With respect to LATD ratio, the average value for liquidity measure is 17.61 and there is a significant difference in degree of the liquidity that banks hold over the sample period as some banks hold higher levels of liquid assets (as high as 281.40), while others almost none.

\section{METHODOLOGY}

To examine the relationship between competition and risk-taking, the model to be estimated includes variables from various studies on risk, competition and capital regulation, and size in banking (De Bandt and Davis, 2000; De Nicolo, 2000; Bikker and Haaf, 2002; Claessens and Leaven, 2004; Demirgünç-Kunt et al., 2004; Gelos and Roldos, 2004; Gonzalez, 2005; Beck et al., 2006; Casu and Girardone, 2006; Wagner, 2007; Altunbas et al., 2007; Carbo et al., 2009; Uhde and Heimeshoff, 2009; Yaldız and Bazzana, 2010; Liu et al., 2012; Liu and Wilson, 2012; Tabak et al., 2012; Jimenez et al., 2013). The general empirical model to be estimated is as follows:

Risk $_{i, t} f\left(\right.$ Competition $_{t}$, bank control variables $_{i, t}$, macroeconomic variables $_{t}$ (1)

where the $i$ subscript refers to a bank and $t$ subscript refers to a sample year. The model sets the relationship between bank risk measure and competition, controlling for bank specific characteristics and macroeconomic variables.

Under static relationship, the studies in the literature usually apply fixed effects and random effects models. However, taking the dynamic relationship consideration, these two methods will produce biased results and inconsistent estimates (see Baltagi, 2001). Therefore, as a dynamic panel data analysis, Generalized Methods of Moments (GMM) suggested by Arellano and Bond (1991) is also applied. GMM proposed by Arellano and Bond (1991) controls the potential endogenous explanatory variables and eliminates the time-invariant firm-specific effect by differentiating the regression equation. Additionally, by employing two or more lagged values of the explanatory variables as instruments, Arellano and Bond (1991) first difference GMM estimator is able to solve the correlation problem between the new error term and the lagged dependent variable.

The econometric analysis adopted in this study involves four steps. Before proceeding to the identification of a possible relationship, all variables need to be tested for stationarity to determine the order of integration. If the order of integration is zero, the series is considered to be stationary, and hence, there is no unit rot. This study uses reliable and well-behaved panel unit root tests, such as those developed by Levin, Lin and Chu (LLC, 2002) and Im, Pesaran and Shin (IPS, 2003), which avoid the problems associated with the traditional unit root test applied to individual time series data. LLC and IPS are based on the null of a unit root. After the presence of unit root is detected in the variables, then, it is to check whether individual effects are fixed or random. As a further step to deal with biasedness and inconsistency of the estimates, GMM dynamic panel estimation technique is used. Finally, some diagnostic tests are provided to check for the robustness of the estimates. 
The IPS (2003) test, which allows for heterogeneity across different panel members, includes different sets of traditional Augmented Dickey Fuller (ADF) regressions ${ }^{5}$. The IPS (2003) test can be specified as follows:

$\Delta y_{i, t}=\alpha_{i}+\beta_{i} y_{i, t-1}+\sum_{j=1}^{p i} \rho_{i, j} \Delta y_{i, t-j}+\varepsilon_{i, t}$

Where $i=1, \ldots \ldots, N$ and $t=1, \ldots \ldots, N$

The error terms are assumed to be independently and normally distributed with zero means, and potentially finite heterogenous variances for all banks and years, whereas lag order $(\rho)$ and $\beta_{i}$ 's are allowed to across banks. The IPS $t$-statistic is the simple average of the individual Dickey Fuller (DF) unit root tests. The IPS test differs from LLC in the sense that all series in the alternative hypothesis of LLC are in the stationary processes, whereas some series can still be non-stationary in the alternative hypothesis of IPS.

In the context of static panel data regression, the general model to be estimated is of the following form:

The actual model specification is as follows:

Risk $_{i, t}=\alpha+\beta_{1}$ Competition $_{t}+\beta_{2}$ Liquidity $_{i, t}+\beta_{3}$ Size $_{i, t}+\beta_{4}$ Lending $_{i, t}+$ $\beta_{5}$ Off-Balance B $_{i, t}+\beta_{6}$ Concentration $_{t}+\beta_{6}$ Economic growth $_{t}+\beta_{7}$ Interest rate $_{t}+$ $\varepsilon_{i, t} \quad \varepsilon_{i, t}=v_{i}+u_{i, t}$

The dependent bank risk variable, $R i_{s} k_{i, t}$ include the risk indicators, Competition is the bank competition, Liquidity, Size, Lending, Off-Balance and Concentration are the bank-specific characteristics and Economic growth gnd Interestrate $_{t}$ are the macroeconomic variables to control the business cycle conditions. As a one-way error component, $\varepsilon_{i, t}$ is the disturbance term, with $v_{i}$ the unobserved bank-specific effect, and $u_{i, t}$ the idiosyncratic error, where $v_{i} \sim \operatorname{IIN}\left(0, \sigma_{v}^{2}\right)$ and independent of $u_{i, t} \sim \operatorname{IIN}\left(0, \sigma_{u}^{2}\right)$. Under the fixed effects model, the $v_{i}$ 's are assumed to be fixed parameters to be estimated, whereas $v_{i}$ 's are assumed to be drawn randomly from a large population. The appropriate model that best fits the sample and the objective of the research must be selected based on the Hausman test. Regarding the main assumption of the random effects estimation, the random effects are not correlated with the explanatory variables. Under the null hypothesis of no correlation between individual effects and regressors, the rejection of null hypothesis supports the random effect to fail, whereas the acceptance of the null makes the random effects estimator the most appropriate choice (Baltagi, 2001). However, since there may be a problem of endogeneity between risk indicators and the explanatory variables, the conventional panel data models may produce biased parameters. Therefore, in order to address these problem estimations, Arellano and Bond (1991) proposed a dynamic Generalized Method of Moments (GMM) estimator model, known as difference GMM, which uses all lagged values of the dependent variable ${ }^{6}$. The dynamic panel GMM model is helpful in amending the potential bias induced by omitted variables in cross-sectional estimates and inconsistency caused by endogeneity. This study adopts the dynamic panel GMM approach to estimate the parameters in first difference form using GMM estimation techniques. To control for endogeneity, the difference GMM estimator adds lagged levels of endogenous regressors, in addition to using the exogenous 
variables as instruments. The validity of the results of the dynamic GMM panel estimator developed by Arellano and Bond (1991) are confirmed by the two specification tests, Sargan test (or Hansen test) and second-order serial correlation test. Sargan test of overidentifying restrictions is designed to test the overall validity of the instruments, and second- order serial correlation test hypothesizes that the error term is not serially correlated (Arellano and Bond, 1991; Arellano and Bover, 1995; Blundell and Bond, 1998). Because first difference is taken, first-order autocorrelation, and no second-order autocorrelation in the residuals should be observed. In general, the failure to reject the null hypothesis of these two specification tests supports the validity of the GMM estimates.

Four bank risk indicators are employed alternatively to measure the risk taking behavior of banks in the Turkish banking sector, namely, ratio of loan-loss provisions over total loans (LLPTL), non-performing loans ratio, measured as the ratio of loans under follow up over total loans (LUFTL), ROA volatility, and $Z$-index. Competition $_{t}$ is measured by H-statistics. Liquidity $_{i, t}$, which is included into the model as bank-specific control variables, is computed from the ratio of total liquid assets over total deposits. It may be expected that relatively more liquid banks are less risky, since liquid assets are a buffer against liquidity shocks (Liu et al., 2012; Köhler, 2012). However, Wagner (2007) suggests that the opposite is in fact the case. Size $e_{i, t}$ is the natural logarithm of total assets. One would expect that larger banks encounter less risk because they are able to better diversify the risks than smaller banks (Berger, 1995; Demsetz and Strahan, 1997; Stiroh, 2006). Additionally, larger banks may have much greater awareness about the risk management systems and instruments compared to smaller banks, and thus, tend to be more stable. However, this is not necessarily the case. On the contrary, larger banks may take on higher levels of risk (De Nicolo, 2000), since they may operate under more competitive pressures (De Bandt and Davis, 2000), and/or they may expect to access to government safety-net measures, which are used to bail out large, distressed banks (O'Hara and Shaw, 1990). As a bankspecific control variable, lending $_{i, t}$, measured as the ratio of total loans over total asset, is included into model to control for the lending behavior of banks. The literature consistently finds that excessive lending activity is associated with greater risk-taking (Altunbas et al., 2007; Jimenez and Saurina, 2007; Foos et al., 2010) ${ }^{7}$, whereas if the ratio of loans over total assets is low, profits will fall, meaning that the banks may be exposed to profitability risks (Liu and Wilson, 2012). Consequently, the impact of lending activity on the bank risks is not clear. Other bank-level explanatory variable of the risk-taking is the Off-Balance - $_{i, t}$ is calculated as the ratio of off-balance sheet items over total assets. Mixed results have been found for the relationship between off-balance sheet items and risk-taking. While Stiroh (2004) and Liu et al. (2012) find that off-balance sheet items are expected to be positively related to risk due to the creation of volatile income, Angbazo (1997) argue that off-balance sheet activities shows evidence of negative impact on bank's riskiness since these activities can help banks to diversify their revenue streams. Concentration $_{t}$ is captured by the ratio of three and five largest banks's assets over the total assets of the banking system, and is used to examine whether concentration has an impact on bank risks (Beck et al., 2006; Uhde and Heimeshoff, 2009, Berger et al., 2009; Liu et al., 2012). 
Meanwhile, when investigating the impact of bank competition on risk-taking behavior of banks, and hence systemic stability, it is vital to control for macroeconomic factors that are likely to affect both market structure and financial stability.Therefore,

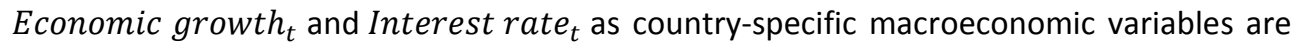
included into all regression models. Economic growth, which is proxied by the growth of real gross domestic product, is employed to control for business cycle conditions, since the banks' activities and operations may be correlated with business cycles (Laven and Majoni, 2003). Bank risk levels are expected to be lower in the economic expansion periods since unemployment rate and insolvency rates should be lower. This will result in a decrease in credit risk and bank portfolio risk (Köhler, 2012). Additionally, during economic expansions, the number of new projects is expected to increase and the projects to be much more profitable in terms of net present value. Therefore, this may reduce the overall credit risk of the bank further (Kashyap et al., 1993). Additionally, a negative effect of growth in GDP on bank risks is expected, since problem loans should increase during economic recession periods (Jimenez et al., 2013). However, banks may encounter more risks during expansion periods if they decide to reduce their screening activity and lending standards (Ruckes, 2004). Finally, Interest rate ${ }_{t}$, as a proxy of lending rate, is included to assess whether interest rates within the countries affect the risk taking of banks. Beck et al., 2006 and Liu et al., 2012 have indicated that, in countries with a higher real interest rate, banks tend to face lower risk due to the associated lower levels of inflation. Lower inflation reduces the overall risk in an environment. Moreover, higher interest rates results in a decline in the lending activity of the banks. As discussed previously, higher lending activity is associated with higher or lower bank risks.

\subsection{Measuring Bank Competition}

Many early studies on bank competition are classified into one of two schools, the "structural" and "non-structural" approaches. Structural approaches are carried out the form of "Structure-Conduct-Performance (SCP)" and "Efficient-Structure-Hypothesis" and both of which focus on profitability while measuring market power. However, due to the empirical and theoretical deficiencies of these two structural approaches, a nonstructural approach has been developed within the framework of "New Empirical Industrial Organization (NEIO) Models. These models give importance to the deviations of output price from marginal cost, and therefore, measure the impact of monopoly and oligopoly powers.

Among these, the Panzar-Rosse (1987) model is one of the most well-known nonstructural techniques to measure bank competition and derived from profit maximizing equilibrium conditions. The Panzar-Rosse model requires the estimation of a reduced form revenue function. Based on P-R model, the $H$-statistics is calculated from the reduced form revenue equation, and is equal to the sum of elasticities of bank revenue with respect to the input prices. In this study, the $H$-statistics is calculated for a pooled bank sample using the revenue equation by using pooled Ordinary Least Squares ${ }^{8}$, as shown in Equation 1:

$$
\begin{aligned}
& \ln \left(r_{i, t}\right)=c+\alpha_{1} \ln \left(p_{1, i, t}\right)+\alpha_{2} \ln \left(p_{2, i, t}\right)+\alpha_{3} \ln \left(p_{3, i, t}\right)+\alpha_{4} \ln \left(b_{1, i, t}\right)+\alpha_{5} \ln \left(b_{2, i, t}\right)+ \\
& \alpha_{6} \ln \left(b_{3, i, t}\right)+\varepsilon_{i, t}
\end{aligned}
$$


where ln denotes the natural logarithm; $r_{i, t}$ the ratio of revenue over total assets for bank $i$ and year $t$ as a proxy for output price of loans; $p_{1, i, t}$ the ratio of interest expenses over total deposits as a proxy for input price of deposits; $p_{2, i, t}$ the ratio of personal expenses over total assets as a proxy for input price of staff; $p_{3, i, t}$ the ratio of other operating expenses over total assets as a proxy for input price of bank physical capital; $b_{1, i, t}$ the ratio of equity over total assets; $b_{2, i, t}$ the ratio of total loans over total assets; $b_{3, i, t}$ total assets. $\theta_{1}$ to $\theta_{6}$ are the coefficients, $c$ is constant, and $\varepsilon_{i, t}$ is the error term. The former three independent variables represent the price factors of bank inputs, whereas the latter three are the control variables, which accounts for size and risk characteristics of banks. The $\mathrm{H}$ statistics equals $\left(\alpha_{1}+\alpha_{2}+\alpha_{3}\right)$. A negative value of $H$ indicates that a banking firm is operating in monopolistic market, whereas $H=0$ suggests that input prices are not correlated with industry returns (Shaffer, 1982). The banking market is perfectly competitive when $H$ is equal to one. The $H$-statistics is positive and less than one in the case of monopolistic competition, namely, firms' revenue increases but by a smaller proportion than firms' costs when input prices increase (Goddard and Wilson, 2009).

\section{EMPIRICAL RESULTS}

\subsection{Panel Unit Root Tests}

Before proceeding to the identification of the possible relationships among the variables, several unit root tests have been proposed to verify that all variables are integrated of the same order. This study uses more reliable and well-behaved panel unit root tests developed by Levin, Lin and Chu (LLC, 2002) and Im, Pesaran and Shin (IPS, 2003). These two tests are based on the null hypothesis of a unit root. The panel unit root test with and without trend results reported in Table 4 clearly indicate that the null hypothesis of a unit root can be rejected by both tests for all variables, except off-balance sheet to total assets ratio. Therefore, it is noted that these variables are stationary in levels. 
Table 4: Panel Unit Root Test

\begin{tabular}{|l|c|c|c|c|}
\hline & \multicolumn{2}{|c|}{$\begin{array}{c}\text { Levin, Lin, Chu (LLC) } \\
\text { Unit Root Test }\end{array}$} & \multicolumn{2}{c|}{$\begin{array}{c}\text { Im Pesaran and Shin (IPS) Unit } \\
\text { Root Test }\end{array}$} \\
\hline & $\begin{array}{c}\text { No } \\
\text { Trend }\end{array}$ & Trend & No Trend & Trend \\
\hline LUF/TL & $-13.080^{*}$ & $-12.988^{*}$ & $-5.481^{*}$ & $-1.878^{* *}$ \\
\hline LLP/TL & $-25.300^{*}$ & $-17.152^{*}$ & $-9.153^{*}$ & $-5.041^{*}$ \\
\hline ROA volatility & $-10.175^{*}$ & $-13.475^{*}$ & $-4.967^{*}$ & $-3.159^{*}$ \\
\hline LNZ-index & $-40.134^{*}$ & $-35.597^{*}$ & $-10.219^{*}$ & $-5.365^{*}$ \\
\hline LNTA & $-12.956^{*}$ & $-19.713^{*}$ & $-4.210^{*}$ & -0.616 \\
\hline LA/TD & $-11.616^{*}$ & $-9.891^{*}$ & $-4.614^{*}$ & $-1.605^{* * *}$ \\
\hline OBS/TA & $-1.350^{* * *}$ & $-7.088^{*}$ & 0.712 & -0.355 \\
\hline TL/TA & $-846.153^{*}$ & $-1655.78^{*}$ & $-198.803^{*}$ & $-121.569^{*}$ \\
\hline I & $-24.127^{*}$ & $-49.152^{*}$ & $-13.238^{*}$ & $-12.044^{*}$ \\
\hline LNGDPG & $-6.935^{*}$ & $-6.111^{*}$ & $-2.271^{*}$ & -0.443 \\
\hline C3 & $-5.984^{*}$ & $-10.620^{*}$ & $-4.901^{*}$ & $-1.532^{* * *}$ \\
\hline C5 & $-10.074^{*}$ & $-6.729^{*}$ & $-4.869^{*}$ & 1.244 \\
\hline HHI-Assets & $-14.628^{*}$ & $-9.505^{*}$ & $-9.848^{*}$ & -0.599 \\
\hline
\end{tabular}

$*, * *$ and $* * *$ denote significance at $0.1,0.05$ and 0.01 levels, respectively.

\subsection{Bank Competition-Risk Analysis}

Appendix 1 reports regression results assessing the impact of competition on systemic stability as measured by the Z-index. Appendix 2-4 presents further empirical results from regressing bank competition and concentration on different bank-risk measures, namely, ROA volatility, LLPTL and LUFTL, respectively. Z-index is the ratio of the sum of ROA and equity-to-asset ratio over the volatility of ROA. ROA volatility is the deviation of individual bank's return on asset (ROA) from the sample mean within one period. LLPTL is the ratio of loan-loss provisions over total loans. LUFTL is the ratio of loans under follow-up over total loans. LNTA is the natural logarithm of total asset of bank as a measure of bank size; LA/TD is the ratio of liquid asset over total deposit as a measure of liquidity; TL/TA is the ratio of total loan over total asset of a bank as a measure of lending; OBS/TA is the ratio of off-balance sheet items over total assets as a measure of off-balance sheet activity; i represents real interest lending rate in Turkish economy; LNGDPG represents the natural logarithm of real GDP growth rate of Turkish economy; C3 denotes the share of the 3 largest banks in the country; C5 denotes the share of the 5 largest banks; HHI-assets is the Herfindahl Index of concentration based on total assets; H-statistics is the measure of bank competition. Model I, II, and III are based on the C3, C5 and HHI-Assets as a proxy for bank concentration, respectively, while Model IV is based H-statistics as a proxy for bank competition. All the appendixes summarize the results of the static and dynamic models, provided in the appendix 1-4. Under the static models, fixed effects and random effects models are estimated to investigate the impact of bank competition, as well as other bank-specific and macroeconomic variables on bank risk-taking. Considering dynamic models, one specification of the GMM method proposed by Arellano and Bond (1991) is used. Among static models, the appropriate methodology is determined through the use 
of specification tests, such as F-test and Hausman test. The significant F-test for all four tables (Appendix 1-4), which specifically sets different dependent variables in regression models, indicates that the fixed effects model outperforms the pooled OLS. Additionally, the Hausman test resulted in a significant Chi-square statistic for all regressions indicate that the fixed effects models are more superior to the random effects models. For model IV in Appendix 1, where Z-index, used as the dependent variable, measures the safety and soundness of the banking system, it was found that bank competition, measured by the $\mathrm{H}$ statistics, does not induce incentives for banks to take on more risk, since the coefficient is positive and statistically significant at $5 \%$ level. This result supports "competition-stability hypothesis", indicating that increased competition leads to lower bank risk, and increases banks' financial soundness. However, considering the results of the model IV in other fixed effects models of Appendix 2-4, in which ROA volatility, LLPTL, LUFTL are used as the dependent variables, respectively, the coefficient is not found to be statistically significant in the explanation of bank risk- taking. Random effects estimations of the Model IV in Appendix 1, where Z-index is the dependent variable, provide further evidence for the positive impact of the competition on financial stability at $5 \%$ significance level, whereas in Appendix 2, with the inclusion of ROA volatility into regression as the dependent variable, bank competition is found to be negative and statistically significant at $5 \%$ level on bank risk-taking. On the whole, both random effect estimators correspond to the "competition and stability" hypothesis, suggesting that greater levels of competition lead to lower risk-taking by banks. These findings concur with the results of Jayaratne and Strahan (1998), De Nicolo (2000), Boyd et al. (2006), Yegati and Micco (2007) and Koetter and Poghosyan (2009), Schaeck et al. (2009) and Liu et al. (2012), but are inconsistent with the those reported by Rhoades and Rutz (1982), Keeley (1990) and Dick (2006). It is noted that specific evidence supporting the "competition-stability hypothesis" is found in Turkish banking system.

With regards to the impact of bank concentration on bank risk-taking, this study controls for the robustness of the main findings through the definition of different concentration measures. $\mathrm{C} 3$ and $\mathrm{C} 5$, as the biggest 3 and 5 banks in the banking sector with respect to the share of their assets, enter into regression results of Model I and Model II, respectively, and also $\mathrm{HHI}$ as the additional measure of the degree of bank concentration enters into the results of Model III in all tables in the appendixes. Considering the results of the fixed effects estimations, all these concentration measures enter regressions significantly negative at most 10\% level in Appendix 3 and 4, where LLPTL and LUFTL are used as dependent variables. These results suggest that an increase in banking market concentration has a negative impact on risk-taking of Turkish banks, a result which corresponds to the "concentration-stability hypothesis" in theoretical literature, and also confirms earlier empirical findings by Beck et al., (2006a, b), Liu et al., (2012), but inconsistent with the result of De Nicolo et al. (2004) and Uhde and Heimeshoff (2009). Advocates of "concentration-stability hypothesis" suggest that larger banks operating in a more concentrated banking system can increase profits, and therefore reduce financial fragility by providing banks with higher "capital buffers", which protect them against several macroeconomic and financial shocks (Boyd et al., 2004), However, for the other bank risk measures, the coefficient is not statistically significant. 
Based on random effects estimators, in contrast, only C5 enters the regression significantly negative at the $5 \%$ level in Appendix 3 and 4 , considering the LLPTL and LUFTL as the dependent variables. Interestingly, using ROA volatility as the dependent variables, $\mathrm{C} 5$ and $\mathrm{HHI}$ measures enter the regression significantly positive at $5 \%$ level, promoting the "concentration-fragility hypothesis". Under the GMM dynamic technique, similarly, the positive and significant coefficient estimates of $\mathrm{C} 3, \mathrm{C} 5$ and $\mathrm{HHI}$ concentration measures regarding LLPTL and LUFTL as the dependent variables reveals that as the concentration increases in the banking system, banks are more likely to take higher risks. In consistent with these findings, all three concentration measures enter the regression significantly positive at $5 \%$ level in Appendix 1, where Z-index is used as the dependent variable. This result generally supports the theoretical arguments of the "concentration-stability hypothesis". On the whole, from an empirical standpoint in concentration and risk-taking part, employing both static and dynamic panel data estimation models, these finding accept both "concentration-stability hypothesis" and "concentration-fragility hypothesis" for Turkish banks. These results are in line with those of Berger et al. (2009) and Tabak et al. (2012). Berger et al. (2009), who test the existence of these hypotheses in 30 developed countries' banking sectors, state that evidence that supports one of the hypotheses does not necessarily invalidate the other.

For the bank characteristics, bank size enters the regression significantly negative in both static and dynamic models in all regressions with different risk measures, except Z-index. As expected, this variable enters the regression significantly positive at the $5 \%$ level, which supports the results of the other risk measures. The reason behind this is that even if the three indicators, i.e. ROA volatility, LLPTL, LUFTL are risk measures, Z-index is considered as an inverse measure of risk. These findings suggest that larger banks are less likely to be involved in risky activities compared to small banks. A possible reason is that larger banks may benefit benefit more via economies of scale or risk reduction activities through portfolio diversification (Liang and Rhoades, 1998; Demsetz and Strahan, 1997; Shiers, 2002). Additionally, superior managerial ability at larger banks plays a crucial role in eliminating risky activities. Therefore, these banks do not need to engage in high-risk activities when the environment is more competitive. This result is in line with those of Hughes et al., 2001; Altunbas et al., 2007; Liu et al., 2012; Tabak et al., 2012; Jimenez et al., 2013; whereas it is inconsistent with those of De Bandt and Davis, 2000, De Nicolo, 2000, who state that larger banks are more likely to be exposed to competitive pressures, and also higher levels of risk.

As for the effect of bank liquidity on overall risk levels of banks, static and dynamic models give different results. Using LLPTL and LUFTL risk measures as dependent variables, liquidity variable enters the regression significantly positive at $1 \%$ level in both fixed and random effects estimators, but significantly negative at $1 \%$ and $5 \%$ levels in dynamic GMM models. Despite this seemingly contradictory result, this variable is found to be statistically significant and negative at $1 \%$ levels for all models in static and dynamic estimators in Appendix 2, where ROA volatility is used. A similar outcome holds for the Zindex measure in Appendix 1. The positive and statistically significant coefficient estimates of bank liquidity in both static and dynamic estimators in Appendix 1, revealing that increased liquidity of bank assets increases banking stability. This is because highly liquid banks are expected to benefit directly from stability by encouraging banks to decrease on- 
balance sheet risks, and also by their capacity to easily liquidate assets in a crisis period. This result does not support the findings of Wagner (2007), Altunbas et al. (2007) and Liu et al. (2012).

With regards to other control variables, lending is expected to have a crucial effect on risktaking, therefore, the motive for adding this variable is to take into account bank lending behavior. Surprisingly, bank lending enters the regression significantly negative in most of the models of different estimators in Appendix 2-4, which means that since loan growth is inevitably associated with loan loss reserve levels, banks tend to take on lower level of risk. Concerning Z-index as the dependent variable, the significant and positive coefficient estimates of bank lending variable is not unexpected, banks with higher volumes of loans are less likely to be engaged in risk activities, since a high level of lending may in fact allow banks to be less aggressive in the market due to their expected higher levels of loan-loss reserves. Therefore, the overall stability may be positively impacted. These findings support the results of Altunbas et al., 2007 and Liu et al., 2012. The insignificant coefficient estimate of off-balance sheet variable in most of the regressions in all tables implies this variable does not indicate a significant impact on bank risk taking behaviors.

Regarding the macroeconomic variables, GDP growth rate fails to enter the regressions significantly in any of the models of fixed and random effects estimators in Appendix 1-4. However, under dynamic GMM model, the GDP growth rate is negative and significant at $1 \%$ level, while it is always significant but positive at $1 \%$ level in Appendix 1 and 3, based on LLPTL and Z-index risk measures, respectively. The regression results indicate that banks in a more developed economy tend to face lower level of risk, and therefore, exhibit higher levels of financial stability. This finding is in line with the findings of Kashyap et al., (1993), Beck et al. (2006), Uhde and Heimeshoff (2009) and Jimenez et al. (2013). As a motive for capturing both banks' profitability and reflect overall macroeconomic condition, the sign of the coefficient estimate of deposit interest rate is controversial in static and dynamic estimators. The interest rate is found to be significantly negative at $1 \%$ and $5 \%$ levels in all regressions of the fixed effects models, whereas significant but not an explicit sign in random effect and dynamic GMM models based on the all-risk measures except Zindex. However, using Z-index as dependent variable, interest rate fails to enter all regressions significantly, indicating no significant impact on bank risk- taking behavior.

\subsection{Robustness Checks}

This section provides some commonly used diagnostic tests to evaluate whether the data are consistent with the assumptions of the static and dynamic panel data models. Following the stationarity tests of the panel data, several specification tests are employed to determine the choice of appropriate methodology. Among the static models, the F-test indicates whether fixed effects model outperforms the pooled OLS, and Hausman test determines that the fixed effects model is superior to random effects model. As indicated by the F-test, the relevant F-statistic is statistically significant at $1 \%$ level in all tables in appendixes, Appendix 1, 2, 3 and 4, indicating that fixed effects model is chosen over pooled OLS. Furthermore, the Hausman test, resulted in a statistically significant level in all tables, provides evidence in favor of fixed effects model. The overall estimation results suggest that individual effects are present. Regarding the dynamic panel GMM model, the 
validity of the instruments for our specification is satisfactory in all cases, as shown by Hansen test and second-order autocorrelation test. The last two rows in all appendixes, Appendix 1, 2, 3 and 4 represent the Hansen test (or Sargan test) and AR(2) test results. Hansen test, which examines the overall validity of the instruments, assesses the null hypothesis that the over-identifying restrictions are valid. The p-values of Hansen test reported are used to test the null hypothesis. The $A R(2)$, a second-order serial correlation test, examines the null hypothesis that first-differenced error term is not serially correlated. Hansen test (or Sargan test) statistics for all models in all tables in appendixes are found to be statistically insignificant, suggesting that over-identifying restrictions are valid. Moreover, as expected, in the residuals, there is a significant first-order serial autocorrelation, but no significant second-order autocorrelation.

\section{CONCLUSION}

The purpose of this paper is to determine the impact of competition on bank risk-taking behavior of banks, and also whether bank competition and concentration improves or deteriorates bank stability in Turkey over the period 2002-2011. Although there have been articles concerning this issue in many developed and developing countries, there is a very limited literature on competition and bank risk- taking in Turkey, as one of the emerging countries. Among many measures of bank concentration, using concentration ratio of the three and five largest banks, denoted as C3 and C5, and the Herfindhal-Hirschman index, Turkish banking sector is characterized as non-concentrated. This may be because relatively low total number of banks over the estimation period, due to acquisitions, mergers with foreign banks and liquidation of some banks. Next, Panzar-Rose model is employed to estimate the competitive conditions in Turkish banking industry. The $\mathrm{H}$ statistics computed for the full sample over the period is $0.5353^{9}$, indicating that Turkish commercial banks essentially operate under monopolistic competition. This finding is in line with the estimates of the competitiveness of commercial banks in Turkey by Aktan and Masood (2010), Özcan (2012) and Vardar et al. (2014). As dependent variables, four different risk-taking measures, namely loan loss provision to total loans ratio, ratio of loan-loss provisions over total loans, ROA volatility and Z-index, are employed in both static and dynamic GMM models to estimate the impact of competition on risk-taking behavior of banks. Moreover, in order to evaluate how this relationship changes according to bank-specific and macroeconomic characteristics, the analysis indicates some control variables, such as bank size, liquidity, off-balance sheet, lending, interest rate and growth rate.

Empirical results from panel estimations hold when employing alternative concentration measures, applying variable techniques to get more robust results. The results of both static and dynamic panel data estimation techniques are consistent with the "competition-stability" hypothesis, implying that banks facing high competition take on lower risks than banks experiencing average competition. They confirm empirical findings by Boyd and De Nicolo (2005), Schaeck et al. (2006) and Beck et al. (2006).

With regard to banking market concentration on bank risk-taking behavior, the results show that, in general, bank concentration is negatively correlated to bank risk taking, suggesting that banks in more concentrated markets are less vulnerable to risks. These findings support "concentration-stability" hypothesis and are in line with the findings of 
the empirical studies by Schaeck and Cihak (2007), Schaek et al. (2006) and Beck et al. $(2006 a, b)$. There is clear evidence that in a competitive environment, larger banks face to lower levels of risk than smaller banks. This may be because the scale of larger banks provides a competitive advantage over smaller banks, therefore, reducing the need to take on more risk (Tabak et al., 2012). Even if off-balance sheet does not have an explanatory power on bank risk-taking in all models and estimators in Turkish banking sector, the findings for liquidity are controversial. However, in general, it can be inferred that as liquidity increases, banks are less likely to engage in risky activities. An explanation for this finding is the expectation that highly liquid banks will benefit from stability through decreasing on-balance sheet activities, and also the ability to liquidate the assets easily and quickly in a crisis period. In correspondence to empirical findings (Altunbas et al., 2007; Liu et al., 2012), lending activity displays some evidence of negative impact on bank riskiness, suggesting that as banks provide higher volumes of loans, they tend to be engaged in less risky activities, due to reflections of higher levels of loan-loss reserves. As a proxy for macroeconomic environment, GDP growth rate has a significant and negative impact on bank risk-taking behavior. An explanation for this finding is that banks in more developed economies tend to take on lower levels of risk, and therefore, exhibit higher levels of financial stability and soundness. However, there is some little evidence supporting the idea that higher interest rates discourages banks from engaging in risky activities, since a higher deposit rate actually increases bank interest income. To sum up, for the banking system as a whole, the main finding is that competition does not increase bank-risk taking, and the results are robust in different model specifications and estimations. The findings are in line with the arguments of the "competition-stability" hypothesis, and confirm empirical findings on Turkish banking by Tunay (2009) and Yaldız and Bazzana (2010).

By addressing a gap in the Turkish banking literature by employing different model specifications and estimation techniques, some policy implications can be deduced from the empirical results of this study. First, low levels of competition and concentration in the Turkish banking sector bring some limitations and disadvantages, such as reduced contributions to the financing of the real economy, and the unfair allocation of credits. These limitations are crucial, especially in Turkey, which is an emerging economy and is exposed to systemic bank failures. Therefore, competition should be encouraged in Turkish banking sector. Additionally, since higher competition leads to a reduction in bank risk taking behavior and to greater stability, competition policies again should be considered as a policy action by the government in order to strengthen the stability of the banking system. The entry restrictions should be revised for smaller banks to promote a more efficient and competitive banking system. In addition, to ensure the continuation of a more competitive system, monitoring and supervising systems should be put in place.

\section{ENDNOTES}

1. Franchise value is the present value of all expected profits that the company would like to realize. It is also referred to 'charter value'.

2. Wagner (2010) contradicts the results of Boyd and Nicolo (2005) in the sense that if it is assumed that banks can choose among different types of borrowers, in a more competitive market, banks are willing to invest in more risky projects in order to maintain their optimal risk-taking level. 
3. See for Table 1 for the list of deposit banks used in the study.

4. Bongini et al. (2002) and Laeven (2006) specify the limitations of using accounting measures of bank risk and focus on the other types of risk measures. However, due to the limited number of listed banks in Turkey, it is not robust to use the other approaches mentioned in their studies. Therefore, we have to follow the same methods as the most of the previous studies in the literature.

5. Traditional ADF test is used to test for the presence of unit roots in univariate time series data.

6. Generally, Arellano and Bond (1991) propose one-step and two-step estimator for the differenced GMM. In this paper, two-step GMM estimator is used since the two-step estimator is asymptotically more efficient than one-step estimator based on the easing the independence and homoscedasticity assumptions of the first-step, by constructing a consistent estimate of the variance and covariance matrix from the residuals of the first step (Beck and Levine, 2004).

7. Banks raise lending activity by relaxing collateral requirements and/or lowering lending standards, such as granting loans to the customers who have not been given a loan by other banks due to their low loan rate or having insufficient collateral (Foos et al., 2010). Therefore, those banks are exposed to more risk.

8. Different from most of the previous studies, for a more robust analysis, in addition to pooled Ordinary Least Squares (OLS), the fixed-effects Generalized Least Squares (GLS), and the one-step system Generalized Method of Moments (GMM) dynamic panel estimator methods are also used to compute the $\mathrm{H}$-statistics. The $\mathrm{H}$-statistic reported and used in the analysis is the result of Pooled Ordinary Least Squares (OLS), if required, the results of other models are available on request.

9. Different from most of the previous studies, for a more robust analysis, pooled Ordinary Least Squares (OLS), the fixed-effects Generalized Least Squares (GLS), and the one-step system Generalized Method of Moments (GMM) dynamic panel estimator methods are used to compute the $H$-statistics. All results support the evidence of monopolistic competition in Turkish banking environment. The H-statistic reported here is the result of Pooled Ordinary Least Squares (OLS), if required, the results of other models are available on request. 


\section{REFERENCES}

- Aktan, B., and O. Masood, 2010, "The State of Competition of the Turkish Banking Industry: An Application of the Panzar-Rosse Model," Journal of Business and Management 11, 131-145.

- Allen, F., and D. Gale, 2000, "Financial Contagion," The Journal of Political Economy 108(1), 1-33.

- Allen, F., and D. Gale, 2004, "Competition and Financial Stability," Journal of Money, Credit and Banking 26(3), 453-480.

- $\quad$ Altunbas, Y., S. Carbo, E. P. M. Gardener, and P. Molyneux, 2007, "Examining the Relationships Between Capital, Risk and Efficiency in European Banking," European Financial Management 13, 49-70.

- Arellano, M., and S. Bond, 1991, "Some Tests of Specification for Panel Data: Monte Carlo Evidence and an Application to Employment Equations," Review of Economic Studies 58, 277-297.

- Arellano, M., and O. Bover, 1995, "Another Look at the Instrumental Variable Estimation of Error-Components Models," Journal of Econometrics 68, 29-51.

- $\quad$ Ariss, R.T., 2010, “On the Implications of Market Power in Banking: Evidence from Developing Countries," Journal of Banking and Finance 34(4), 765-775.

- Baltagi, B., 2001, Econometric Analysis of Panel Data UK: John Wiley \& Sons Ltd., 2nd Ed.

- Beck, T., and R. Levin, 2004, "Stock Markets, Banks, and Growth: Panel Evidence," Journal of Banking and Finance 28(3), $423-442$.

- Beck, T., A. Demirguc-Kunt, and R. Levine, 2006, "Bank Concentration, Competition, and Crises: First Results," Journal of Banking and Finance 30(5), 1581-1603.

- Berger, A. N., L. Klapper,, and R. Turk-Ariss, 2009, “Bank Competition and Financial Stability," Journal of Financial Services 35( 2), 99-118.

- Besanko, D., and A.V. Thakor, 1993, "Relationship Banking, Deposit Insurance and Bank Portfolio," In: Capital Market and Financial Intermediation, edited by Mayer, C., and X. Vives, 262-265. Cambridge, UK: Cambridge University Press.

- Bikker, J. A., and K. Haaf, 2002, "Competition, Concentration and Their Relationship: An Empirical Analysis of the Banking Industry," Journal of Banking and Finance 26, 2191-2214. 
- Blundell, R., and S. Bond, 1998, "Initial Conditions and Moment Restrictions in Dynamic Panel Data Models," Journal of Econometrics 87, 115-143.

- Bofondi, M., and G. Gobbi, 2004, "Bad Loans and Entry Into Local Credit Markets," Temi di Discussione del Servizio Studi 509, Bank of Italy.

- Bongini, P., L. Laeven, and G. Majnoni, 2002, "How Good is the Market at Assessing Bank Fragility? A Horse Race Between Different Indicators," Journal of Banking and Finance 26, 1011-1028.

- Boyd, J. H., and G. De Nicolo, 2005, "The Theory of Bank Risk Taking and Competition Revisited," Journal of Finance 60, 1329-1343.

- Boyd, J.H., G. De Nicolo, and A. Al Jalal, 2006, "Bank Risk Taking and Competition Revisited: New Theory And New Evidence," International Monetary Fund Working Paper 06/297.

- Boyd, J.H., G. De Nicoló, and B.D. Smith, 2004, "Crises in Competitive Versus Monopolistic Banking Systems," Journal of Money, Credit and Banking 36, 487506.

- Brewer, E.III., and M.R. Saidenberg, 1996, "Franchise Value, Ownership Structure, and Risk at Savings Institutions" Federal Reserve Bank of New York Research Paper 9632.

- Carbo, S., D. Humphrey, J. Maudos, and P. Molyneux, 2009, "Cross-Country Comparisons of Competition and Pricing Power in European Banking," Journal of International Money and Finance 28, 115-34.

- Carletti, E., (2005), Competition and Regulation in Banking. Center for Financial Studies.

- Casu, B., and C. Girardone, 2006, "Bank Competition, Concentration and Efficiency In The Single European Market," The Manchester School 74, 441-468.

- Chan, Y.S., S. Greenbaum, and A. Thakor, 1986, "Information Reusability, Competition and Bank Asset Quality," Journal of Banking and Finance 10, 243-53.

- Chang, R., and A. Velasco. 2001, "A Model of Financial Crises In Emerging Markets," The Quarterly Journal of Economics 116 (2), 489-517.

- Cho, Y.J, 1986, "Inefficiencies from Financial Liberalization in the Absence of WellFunctioning Equity Markets," Journal of Money, Credit and Banking 26(2), 341344.

- Claessens, S., and L. Laeven. 2004, "What Drives Bank Competition? Some International Evidence," Journal of Money, Credit and Banking 36, 563-84. 
- Cordella, T., and E. L. Yeyati, 2002, "Financial Opening, Deposit Insurance, and Risk in A Model of Banking Competition," European Economic Review 46, 471-485.

- De Bandt, O., and E. P. Davis, 2000, “Competition, Contestability and Market Structure in European Banking Sectors on the Eve of EMU," Journal of Banking and Finance 24, 1045-1066.

- De Nicolo, G., 2000, "Size, Charter Value and Risk in Banking: An International Perspective," International Finance Discussion 689, Board of Governors of the Federal Reserve System.

- De Nicolo, G., P. Bartholomew, J. Zaman, and M. Zephirin, 2004, "Bank Consolidation, Internationalization and Conglomeration: Trends and Implications for Financial Risk," Financial Markets, Institutions and Instruments 13, 173-217.

- De Nicolo, G., and E. Loukoianova, 2007, "Bank Ownership, Market Structure and Risk," Monetary Fund Working Paper: 07/215.

- Demirguc-Kunt, A., L. Laeven, and R. Levine, 2004, "Regulations, Market Structure, Institutions, and the Cost of Financial Intermediation," Journal of Money, Credit and Banking 36, 593-622.

- Demsetz, R. S., and P. E. Strahan, 1997, "Diversification, Size, and Risk at Bank Holding Companies," Journal of Money, Credit and Banking 29, 300-313.

- Demsetz, R.S., M.R. Saidenberg, and P.E. Strahan, 1996, "Banks with Something to Lose: the Disciplinary Role of Franchise Value," FRBNY Economic Policy Review October,1-14.

- Dick, A., 2006, "Nationwide Branching and Its Impact on Market Structure, Quality and Bank Performance," Journal of Business 79, 567-592.

- Dickey, D. A., and W.A. Fuller, 1979, "Distribution of The Estimators for Autoregressive Time Series with a Unit Root," Journal of the American Statistical Association 74, 427-431.

- Dornbush, R., and A. Reynoso, 1989, "Financial Factors in Economic Development," American Economic Review 79(2), 204-209.

- Foos, D., L. Norden, and M. Weber, 2010, "Loan Growth and Riskiness of Banks," Journal of Banking and Finance 34(12), 2929-2940.

- Fry, M.J., 1988, “Money. Interest and Banking in Economic Development," Baltimore: The John Hopkins University Press,

- Fungáčová, Z., and L. Weill, 2009, "How Market Powers Influences Bank Failures: Evidence from Russia," Working Paper, Bank of Finland. 
- $\quad$ Furlong, F.T., and M.C. Keeley, 1989, "Bank Capital Regulation and Risk Taking: A Note," Journal of Banking and Finance 13, 883-891.

- Gelos, R. G., and J. Roldos, 2004, "Consolidation and Market Structure in Emerging Banking Systems," Emerging Markets Review 5, 39-59.

- Goddard, J., and J. O. S. Wilson, 2009, "Competition in Banking: A Disequilibrium Approach," Journal of Banking and Finance 32, 2282-2292.

- Gonzalez, F., 2005, "Bank Regulation and Risk-Taking Incentives: An International Comparison of Bank Risk" Journal of Banking and Finance 29, 1153-1184.

- Hellmann, T.F., K.C. Murdock, and J.E. Stiglitz, 2000, "Liberalization, Moral Hazard in Banking, and Prudential Regulation: Are Capital Requirements Enough?" American Economic Review 90(1), 147-165.

- Hong L., and J.O.S. Wilson, 2012, Competition and Risk in Japanese Banking," The European Journal of Finance, DOI:10.1080/1351847X.2011.633614.

- Hong L., P. Molyneux, and L. H. Nguyen, 2012, "Competition and Risk in South East Asian Commercial Banking," Applied Economics 44(28), 3627-3644.

- Im, K. S., M. H. Pesaran, and Y. Shin, 2003, "Testing for unit roots in heterogeneous panels," Journal of Econometrics 115(1), 53-74.

- Jayaratne, J., and P.E. Strahan, 1998, "Entry Restrictions, Industry Evolution, and Dynamic Efficiency: Evidence from Commercial Banking," Journal of Law and Economics April (XLI), 239-273.

- Jensen, K., 1989, "Monetary policy and financial development", In: Financing Economic Development: A Structural Approach of Economic Development, edited by E.V.K.Fitzgerald, and R.Vos. Gower. Brookfield: .Publishing Company Ltd.

- Jimenez, G., J.A. Lopez, and J. Saurinaa. 2013, “How Does Competition Affect Bank Risk-taking?" .Journal of Financial stability 9, 185-195.

- Jimenez, G., J.A. Lopez, and J. Saurina, 2008, "How Does Competition Impact Bank Risk Taking" Working Paper. Bank of Spain.

- Kashyap, A.K., J.C. Stein, and D.W Wilcox. 1993. "Monetary Policy and Credit Conditions: Evidence from the Composition of External Finance." The American Economic Review 83(1): 78-98.

- Keeley, M.C., 1990, “Deposit Insurance, Risk and Market Power in Banking," American Economic Review 80, 1183-1200. 
- $\quad$ Koetter, M., and T. Poghosyan, 2009, "The Identification of Technology Regimes in Banking: Implications for the Market Power-Financial Fragility Nexus," Journal of Banking and Finance 33, 1413-1422.

- Köhler, M., 2012, "Which Banks are More Risky? The Impact of Loan Growth and Business Model on Bank Risk-taking," Deutsche Bundesbank Discussion Paper: $33 / 2012$.

- Laven, L., 2006, "Banking Sector Performance in East Asian Countries: The Effects of Competition, Diversification, And Ownership. A background paper for 'East Asian Finance: The Road to Robust Markets," Mimeo, World Bank.

- Laven, L., and G. Majoni, 2003, "Loan Loss Provisioning and Economic Slowdowns: Too Much, Too Late?," Journal of Financial Intermediation 12, 178197.

- Levin, A., C. Lin, and C. James Chu., 2002, "Unit Root Tests in Panel Data: Asymptotic and Finite-Sample Properties," Journal of Econometrics 108(1), 1-24.

- Marcus, A.J., 1984, "Deregulation and Bank Financial Policy," Journal of Banking and Finance 8, 557-565.

- Marquez, R. 2002, “Competition, Adverse Selection, and Information Dispersion in the Banking Industry," Review of Financial Studies 15, 901-926.

- Martinez-Miera, D., and R. Repullo, 2010, "Does Competition Reduce the Risk of Bank Failure?," Review of Financial Studies 23(10), 3638-3664.

- Matutes, C., and X. Vives, 1996, "Competition for Deposits, Fragility, and Insurance," Journal of Financial Intermediation 5, 184-216.

- Matutes, C., and X. Vives, 2000, "Imperfect Competition, Risk Taking and Competition in Banking," European Economic Review 44, 1-34.

- Nash, R. C., and J. F. Sinkey, 1997, "On Competition, Risk, and Hidden Assets in the Market for Bank Credit Cards,' Journal of Banking and Finance 21, 89-112.

- O'Hara, M., and S. Wayne, 1990, "Deposit Insurance and Wealth Effects: The Value of Being 'Too Big To Fail,'” Journal of Finance 45, 1587-1600.

- Özcan, A, 2012, “Türkiye'de Ticari Bankacılık Sektöründe Rekabet Düzeyinin Belirlenmesi (2002-2009)," Cumhuriyet Üniversitesi, iktisadi ve Idari Bilimler Dergisi 13(1), 195-211.

- Panzar, J.C., and J.N. Rosse, 1987, "Testing for Monopoly Equilibrium," Journal of Industrial Economics 35, 443-456. 
- $\quad$ Rhoades, S.A., and R.D. Rutz, 1982, "Market Power and Firm Risk. A Test of the 'Quiet Life' Hypothesis," Journal of Monetary Economics 9, 73-85.

- Ruckes, M. 2004, "Bank Competition and Credit Standards," The Review of Financial Studies 17(4), 1073-1102.

- Sáez, L., and X. Shi, 2004, “Liquidity Pools, Risk Sharing, and Financial Contagion” Journal of Financial Services Research 25(1), 5-23.

- Salas, V., and J. Saurina, 2003, "Deregulation, Market Power and Risk Behavior in Spanish Banks," European Economic Review 47, 1061-1075.

- Saunders, A., and B. Wilson, 1996, "Bank Capital Structure: Charter Value and Diversification Effects," Working Paper: S-96-52, New York University Salomon Center.

- Schaeck, K., and M. Čihák, 2007, "Banking Competition and Capital Ratios," IMF Working Paper: 07/216. Washington: International Monetary Fund.

- Schaek, K., M. "Cihak, and S. Wolfe, 2006, "Are More Competitive Banking Systems More Stable?," IMF Working Paper: 06/143.

- Shaffer, S., 1982, "A Non-Structural Test for Competition in Financial Markets," In Proceedings of a Conference on Bank Structure and Competition by Federal Reserve Bank of Chicago, 225-243. Chicago.

- Soedarmono, W., F. Machrouh, and A. Tarazi, 2011, "Bank Market Power, Economic Growth and Financial Stability: Evidence from Asian Banks," Journal of Asian Economics 22( 6), 460-470.

- Soedarmono, W., F. Machrouh, and A. Tarazi, 2013, "Bank Competition, Crisis and Risk Taking: Evidence from Emerging Markets in Asia," Journal of International Financial Markets, Institutions \& Money 23, 196-221.

- Stiglitz, J., and A. Weiss, 1981, "Credit Rationing in Markets with Imperfect Information," American Economic Review 71(3), 393-410.

- Stiroh, K. J., 2004, "Diversification in Banking: Is Noninterest Income the Answer?," Journal of Money, Credit and Banking 36, 853-882.

- $\quad$ Stiroh, K., and A. Rumble, 2006, "The Dark Side of Diversification: The Case of US Financial Holding Companies," Journal of Banking and Finance 30, 2131-2161.

- Tabak, B., D. Fazio, and D. Cajueiro, 2012, "The Relationship between Banking Market Competition and Risk-Taking: Do Size and Capitalization Matter?," Journal 
of Banking and Finance 36(12), 3366-3381.

- Taylor, L., 1983, Structuralist Macroeconomics: Applicable Models for the Third World. New-York: Basic Books.

- Tunay, B., 2009, "Turk Bankacılık Sektorunde Rekabet ve Kırılganlık," Bankacılar Dergisi 68, 30-54.

- Uhde, A., and U. Heimeshoff, 2009, "Consolidation in Banking and Financial Stability in Europe: Empirical Evidence," Journal of Banking and Finance 33, 1299311.

- Vives, X., 2010, “Competition and Stability in Banking," CESifo Working Paper 3050(11), Industrial Organization.

- Wagner, W., 2007, "The Liquidity of Bank Assets and Banking Stability," Journal of Banking and Finance 31, 121-39.

- Wagner, W., 2010, "Loan market competition and bank risk-taking," Journal of Financial Services Research 37(1), 71-81.

- Yaldız, E., and F. Bazzana, 2010, "The Effect of Market Power on Bank Risk Taking in Turkey," Financial Theory and Practice 34(3), 297-314.

- Yeyati, E. L., and A. Micco, 2007, "Concentration and Foreign Penetration in Latin American Banking Sectors: Impact on Competition and Risk," Journal of Banking and Finance 31, 1633-47. 


\section{APPENDIXES}

Appendix 1: Estimation Results: Competition and Bank Risk Taking

\begin{tabular}{|c|c|c|c|c|c|c|c|c|c|c|c|c|}
\hline \multirow{3}{*}{$\begin{array}{l}\text { Dependent } \\
\text { Variable: Z-index }\end{array}$} & \multicolumn{8}{|c|}{ Static Models } & \multirow{2}{*}{\multicolumn{4}{|c|}{$\begin{array}{c}\text { Dynamic Models } \\
\text { Differenced -GMM }\end{array}$}} \\
\hline & \multicolumn{4}{|c|}{ Fixed Effects } & \multicolumn{4}{|c|}{ Random Effecst Model } & & & & \\
\hline & Model I & Model II & $\begin{array}{l}\text { Model } \\
\text { III }\end{array}$ & Model IV & Model I & Model II & Model III & Model IV & Model I & Model II & Model III & Model IV \\
\hline LNTA & $\begin{array}{c}-0.053 \\
(0.771)\end{array}$ & $\begin{array}{c}0.041 \\
(0.806)\end{array}$ & $\begin{array}{c}0.022 \\
(0.900)\end{array}$ & $\begin{array}{l}-0.030 \\
(0.857)\end{array}$ & $\begin{array}{c}0.071 \\
(0.286)\end{array}$ & $\begin{array}{c}0.079 \\
(0.246)\end{array}$ & $\begin{array}{c}0.076 \\
(0.257)\end{array}$ & $\begin{array}{c}0.071 \\
(0.283)\end{array}$ & $\begin{array}{c}0.754^{* *} \\
(0.045)\end{array}$ & $\begin{array}{c}0.383 * * * \\
(0.098)\end{array}$ & $\begin{array}{c}0.768^{* *} \\
(0.018)\end{array}$ & $\begin{array}{c}0.010 \\
(0.959)\end{array}$ \\
\hline$L A / T D$ & $\begin{array}{l}0.007^{*} \\
(0.000)\end{array}$ & $\begin{array}{l}0.008^{*} \\
(0.000) \\
\end{array}$ & $\begin{array}{l}0.007^{*} \\
(0.000) \\
\end{array}$ & $\begin{array}{l}0.007^{*} \\
(0.000) \\
\end{array}$ & $\begin{array}{l}0.002 * \\
(0.000)\end{array}$ & $\begin{array}{l}0.003 * \\
(0.000)\end{array}$ & $\begin{array}{l}0.003 * \\
(0.000)\end{array}$ & $\begin{array}{l}0.002 * \\
(0.000)\end{array}$ & $\begin{array}{l}0.017^{*} \\
(0.000) \\
\end{array}$ & $\begin{array}{l}0.016^{*} \\
(0.000) \\
\end{array}$ & $\begin{array}{l}0.016 * \\
(0.000)\end{array}$ & $\begin{array}{l}0.013^{*} \\
(0.004) \\
\end{array}$ \\
\hline$T L / T A$ & $\begin{array}{c}1.468^{* * *} \\
(0.069)\end{array}$ & $\begin{array}{c}1.612^{* *} \\
(0.044)\end{array}$ & $\begin{array}{c}1.608^{* *} \\
(0.046)\end{array}$ & $\begin{array}{c}1.545^{* * *} \\
(0.051)\end{array}$ & $\begin{array}{c}0.560 \\
(0.291)\end{array}$ & $\begin{array}{c}0.655 \\
(0.214)\end{array}$ & $\begin{array}{c}0.636 \\
(0.231)\end{array}$ & $\begin{array}{c}0.603 \\
(0.237)\end{array}$ & $\begin{array}{c}3.335^{* *} \\
(0.031)\end{array}$ & $\begin{array}{c}2.679 * * * \\
(0.054)\end{array}$ & $\begin{array}{c}3.345^{* *} \\
(0.016)\end{array}$ & $\begin{array}{l}5.925^{*} \\
(0.000)\end{array}$ \\
\hline$O B S / T A$ & $\begin{array}{c}0.030 \\
(0.406)\end{array}$ & $\begin{array}{c}0.030 \\
(0.407)\end{array}$ & $\begin{array}{c}0.029 \\
(0.413)\end{array}$ & $\begin{array}{c}0.017 \\
(0.635)\end{array}$ & $\begin{array}{c}-0.001 \\
(0.954)\end{array}$ & $\begin{array}{l}0.0006) \\
(0.974)\end{array}$ & $\begin{array}{l}-0.0003 \\
(0.987)\end{array}$ & $\begin{array}{l}-0.009 \\
(0.701)\end{array}$ & $\begin{array}{c}0.024 \\
(0.559)\end{array}$ & $\begin{array}{c}0.010 \\
(0.562)\end{array}$ & $\begin{array}{c}0.008 \\
(0.812)\end{array}$ & $\begin{array}{c}-0.111 \\
(0.136)\end{array}$ \\
\hline$i$ & $\begin{array}{c}0.003 \\
(0.788)\end{array}$ & $\begin{array}{c}0.018 \\
(0.161)\end{array}$ & $\begin{array}{c}0.006 \\
(0.694)\end{array}$ & $\begin{array}{c}0.005 \\
(0.606)\end{array}$ & $\begin{array}{l}-0.002 \\
(0.755)\end{array}$ & $\begin{array}{c}0.010 \\
(0.226)\end{array}$ & $\begin{array}{l}-0.004 \\
(0.645)\end{array}$ & $\begin{array}{c}-0.0006 \\
(0.919)\end{array}$ & $\begin{array}{c}0.017 \\
(0.498)\end{array}$ & $\begin{array}{l}-0.006 \\
(0.715 \\
\end{array}$ & $\begin{array}{c}0.050 \\
(0.264)\end{array}$ & $\begin{array}{l}-0.050 * \\
(0.004)\end{array}$ \\
\hline$\angle N G D P G$ & $\begin{array}{l}-0.773 \\
(0.673)\end{array}$ & $\begin{array}{c}0.206 \\
(0.918)\end{array}$ & $\begin{array}{l}-0.927 \\
(0.648)\end{array}$ & $\begin{array}{c}0.630 \\
(0.740)\end{array}$ & $\begin{array}{l}-0.879 \\
(0.708)\end{array}$ & $\begin{array}{c}0.045 \\
(0.983)\end{array}$ & $\begin{array}{l}-1.373 \\
(0.579)\end{array}$ & $\begin{array}{c}0.583 \\
(0.820)\end{array}$ & $\begin{array}{l}1.426^{*} \\
(0.001)\end{array}$ & $\begin{array}{l}1.207^{*} \\
(0.007)\end{array}$ & $\begin{array}{l}3.028^{*} \\
(0.006)\end{array}$ & $\begin{array}{l}-1.104 \\
(0.353)\end{array}$ \\
\hline CR3 & $\begin{array}{l}-7.613 \\
(0.192)\end{array}$ & & & & $\begin{array}{l}-7.757 \\
(0.104)\end{array}$ & & & & $\begin{array}{c}10.625^{* *} \\
(0.039)\end{array}$ & & & \\
\hline CR5 & & $\begin{array}{c}7.814 \\
(0.370)\end{array}$ & & & & $\begin{array}{c}9.470 \\
(0.166)\end{array}$ & & & & $\begin{array}{c}6.659 * * \\
(0.025)\end{array}$ & & \\
\hline HHI-Assets & & & $\begin{array}{c}-19.583 \\
(0.680)\end{array}$ & & & & $\begin{array}{l}-29.685 \\
(0.473)\end{array}$ & & & & $\begin{array}{c}117.148 * * * \\
(0.068)\end{array}$ & \\
\hline$H$-statistics & & & & $\begin{array}{c}0.820^{* *} \\
(0.031)\end{array}$ & & & & $\begin{array}{c}0.889 * * \\
(0.025)\end{array}$ & & & & $\begin{array}{l}-0.045 \\
(0.878)\end{array}$ \\
\hline Number of obs & 266 & 266 & 266 & 266 & 266 & 266 & 266 & 266 & 187 & 187 & 187 & 187 \\
\hline F-statistic & $2.881^{*}$ & $2.879 *$ & $2.875^{*}$ & $2.870^{*}$ & & & & & & & & \\
\hline Hausman test & & & & & $19.682^{*}$ & $21.418^{*}$ & $20.655^{*}$ & $19.856^{*}$ & & & & \\
\hline$R$-squared & 0.276 & 0.273 & 0.271 & 0.276 & 0.276 & 0.203 & 0.253 & 0.253 & & & & \\
\hline Hansen ( $p$ value) & & & & & & & & & 0.227 & 0.244 & 0.247 & 0.207 \\
\hline$A R(2)$ & & & & & & & & & 0.194 & 0.234 & 0.150 & 0.167 \\
\hline
\end{tabular}

Note: ${ }^{* * *}$ and ${ }^{* * *}$ denotes statistical significance at the $1 \%, 5 \%$ and $10 \%$ level, respectively. 
Appendix 2: Estimation Results: Competition and Bank Risk Taking

\begin{tabular}{|c|c|c|c|c|c|c|c|c|c|c|c|c|}
\hline \multirow{3}{*}{$\begin{array}{l}\text { Dependent } \\
\text { Variable: ROA } \\
\text { Volatility } \\
\end{array}$} & \multicolumn{8}{|c|}{ Static Models } & \multirow{2}{*}{\multicolumn{4}{|c|}{$\begin{array}{c}\text { Dynamic Models } \\
\text { Differenced -GMM }\end{array}$}} \\
\hline & \multicolumn{4}{|c|}{ Fixed Effects } & \multicolumn{4}{|c|}{ Random Effecst Model } & & & & \\
\hline & Model I & Model II & Model III & Model IV & Model I & Model II & Model III & Model IV & Model I & Model II & Model III & Model IV \\
\hline LNTA & $\begin{array}{l}-0.003^{*} \\
(0.001) \\
\end{array}$ & $\begin{array}{l}-0.003^{*} \\
(0.000) \\
\end{array}$ & $\begin{array}{l}-0.003^{*} \\
(0.000) \\
\end{array}$ & $\begin{array}{l}-0.004^{*} \\
(0.000) \\
\end{array}$ & $\begin{array}{c}-0.0007^{* *} \\
(0.035)\end{array}$ & $\begin{array}{c}-0.0008^{* *} \\
(0.037)\end{array}$ & $\begin{array}{c}-0.0007^{* *} \\
(0.036)\end{array}$ & $\begin{array}{c}-0.0007^{* *} \\
(0.038)\end{array}$ & $\begin{array}{l}-0.003^{*} \\
(0.000)\end{array}$ & $\begin{array}{l}-0.004^{*} \\
(0.000) \\
\end{array}$ & $\begin{array}{l}-0.004 * \\
(0.000) \\
\end{array}$ & $\begin{array}{l}-0.006^{*} \\
(0.000)\end{array}$ \\
\hline$L A / T D$ & $\begin{array}{c}- \\
0.00009 * \\
(0.000) \\
\end{array}$ & $\begin{array}{c}-0.00009 * \\
(0.000)\end{array}$ & $\begin{array}{c}-0.00009 * \\
(0.000)\end{array}$ & $\begin{array}{c}-0.00009 * \\
(0.000)\end{array}$ & $\begin{array}{c}0.000003 \\
(0.435)\end{array}$ & $\begin{array}{c}0.000002 \\
(0.651)\end{array}$ & $\begin{array}{c}0.000002 \\
(0.516)\end{array}$ & $\begin{array}{c}0.000002 \\
(0.655)\end{array}$ & $\begin{array}{c}-0.0002 * \\
(0.000)\end{array}$ & $\begin{array}{c}-0.0002^{*} \\
(0.000)\end{array}$ & $\begin{array}{c}-0.0002^{*} \\
(0.000)\end{array}$ & $\begin{array}{c}-0.0002 * \\
(0.000)\end{array}$ \\
\hline$T L / T A$ & $\begin{array}{l}-0.007 \\
(0.139)\end{array}$ & $\begin{array}{l}-0.007 \\
(0.108)\end{array}$ & $\begin{array}{l}-0.007 \\
(0.120)\end{array}$ & $\begin{array}{c}-0.007^{* * *} \\
(0.093)\end{array}$ & $\begin{array}{l}-0.004 \\
(0.139)\end{array}$ & $\begin{array}{l}-0.005 \\
(0.107)\end{array}$ & $\begin{array}{l}-0.005 \\
(0.129)\end{array}$ & $\begin{array}{l}-0.005 \\
(0.117)\end{array}$ & $\begin{array}{l}0.0003 \\
(0.823)\end{array}$ & $\begin{array}{c}0.002 \\
(0.369)\end{array}$ & $\begin{array}{l}0.0006 \\
(0.807)\end{array}$ & $\begin{array}{l}0.006 * * \\
(0.033)\end{array}$ \\
\hline OBS/TA & $\begin{array}{c}-0.00001 \\
(0.369) \\
\end{array}$ & $\begin{array}{c}-0.0001 \\
(0.370) \\
\end{array}$ & $\begin{array}{r}-0.0001 \\
(0.382) \\
\end{array}$ & $\begin{array}{r}-0.0002 \\
(0.332) \\
\end{array}$ & $\begin{array}{c}0.00006 \\
(0.343) \\
\end{array}$ & $\begin{array}{c}0.00004 \\
(0.573)\end{array}$ & $\begin{array}{c}0.00006 \\
(0.328)\end{array}$ & $\begin{array}{c}0.00005 \\
(0.469) \\
\end{array}$ & $\begin{array}{c}-0.00008^{*} \\
(0.000) \\
\end{array}$ & $\begin{array}{c}-0.0001^{*} \\
(0.000)\end{array}$ & $\begin{array}{c}-0.0001^{* *} \\
(0.010) \\
\end{array}$ & $\begin{array}{c}-0.00007 \\
(0.563) \\
\end{array}$ \\
\hline$i$ & $\begin{array}{c}-0.0002 * \\
(0.002) \\
\end{array}$ & $\begin{array}{c}-0.0002^{*} \\
(0.000)\end{array}$ & $\begin{array}{c}-0.0002^{* *} \\
(0.031)\end{array}$ & $\begin{array}{c}-0.0002^{*} \\
(0.000) \\
\end{array}$ & $\begin{array}{c}0.00001 \\
(0.689)\end{array}$ & $\begin{array}{c}-0.00009 \\
(0.302) \\
\end{array}$ & $\begin{array}{c}0.00008^{* * *} \\
(0.053)\end{array}$ & $\begin{array}{c}-0.00002 \\
(0.507)\end{array}$ & $\begin{array}{c}0.000002 \\
(0.925)\end{array}$ & $\begin{array}{c}-0.00001 \\
(0.600) \\
\end{array}$ & $\begin{array}{c}-0.0001 \\
(0.140) \\
\end{array}$ & $\begin{array}{c}-0.0001^{* *} \\
(0.037)\end{array}$ \\
\hline LNGDPG & $\begin{array}{l}0.0003 \\
(0.971)\end{array}$ & $\begin{array}{l}-0.004 \\
(0.695)\end{array}$ & $\begin{array}{c}0.003 \\
(0.799)\end{array}$ & $\begin{array}{c}0.001 \\
(0.921)\end{array}$ & $\begin{array}{c}0.009 \\
(0.380)\end{array}$ & $\begin{array}{c}0.003 \\
(0.616)\end{array}$ & $\begin{array}{c}0.019 \\
(0.192)\end{array}$ & $\begin{array}{c}0.007 \\
(0.475)\end{array}$ & $\begin{array}{l}0.004^{*} \\
(0.002)\end{array}$ & $\begin{array}{c}0.001 \\
(0.165)\end{array}$ & $\begin{array}{c}-0.002 \\
(0.390)\end{array}$ & $\begin{array}{c}-0.001 \\
(0.110)\end{array}$ \\
\hline CR3 & $\begin{array}{c}0.030 \\
(0.377) \\
\end{array}$ & & & & $\begin{array}{l}0.084 * * \\
(0.030) \\
\end{array}$ & & & & $\begin{array}{c}0.001 \\
(0.853) \\
\end{array}$ & & & \\
\hline CR5 & & $\begin{array}{c}-0.042 \\
(0.405) \\
\end{array}$ & & & & $\begin{array}{c}-0.071 \\
(0.287) \\
\end{array}$ & & & & $\begin{array}{c}-0.013 \\
(0.239)\end{array}$ & & \\
\hline HHI-Assets & & & $\begin{array}{c}0.188 \\
(0.500)\end{array}$ & & & & $\begin{array}{l}0.586^{* *} \\
(0.023)\end{array}$ & & & & $\begin{array}{l}-0.298 \\
(0.105)\end{array}$ & \\
\hline $\mathrm{H}$-statistics & & & & $\begin{array}{c}0.001 \\
(0.639)\end{array}$ & & & & $\begin{array}{l}0.001^{* *} \\
(0.016)\end{array}$ & & & & $\begin{array}{c}-0.001 * * * \\
(0.063)\end{array}$ \\
\hline No.ofobs & 226 & 226 & 226 & 226 & 226 & 226 & 226 & 226 & 187 & 187 & 187 & 187 \\
\hline F-statistic & $5.722^{*}$ & $5.950 *$ & $5.806^{*}$ & $5.974 *$ & & & & & & & & \\
\hline Hausman test & & & & & $99.216^{*}$ & $97.378^{*}$ & $96.264^{*}$ & $97.586^{*}$ & & & & \\
\hline$R$-Squared & 0.463 & 0.462 & 0.462 & 0.461 & 0.441 & 0.426 & 0.462 & 0.461 & & & & \\
\hline $\begin{array}{l}\text { Hansen ( } p \\
\text { value) }\end{array}$ & & & & & & & & & 0.602 & 0.604 & 0.661 & 0.612 \\
\hline$A R(2)$ & & & & & & & & & 0.564 & 0.797 & 0.884 & 0.551 \\
\hline
\end{tabular}

Note: ${ }^{* * *}$ and ${ }^{* * *}$ denotes statistical significance at the $1 \%, 5 \%$ and $10 \%$ level, respectively. 
Appendix 3: Estimation Results: Competition and Bank Risk Taking

\begin{tabular}{|c|c|c|c|c|c|c|c|c|c|c|c|c|}
\hline \multirow[t]{3}{*}{$\begin{array}{l}\text { Dependent } \\
\text { Variable: LLPTL }\end{array}$} & \multicolumn{8}{|c|}{ Static Models } & \multirow{2}{*}{\multicolumn{4}{|c|}{$\begin{array}{c}\text { Dynamic Models } \\
\text { Differenced -GMM }\end{array}$}} \\
\hline & \multicolumn{4}{|c|}{ Fixed Effects } & \multicolumn{4}{|c|}{ Random Effecst Model } & & & & \\
\hline & Model I & Model II & Model III & Model IV & Model I & Model II & Model III & Model IV & Model I & Model II & Model III & Model IV \\
\hline LNTA & $\begin{array}{c}-0.448 * * \\
(0.017)\end{array}$ & $\begin{array}{c}-0.297 * * * \\
(0.083)\end{array}$ & $\begin{array}{l}-0.403^{*} \\
(0.026)\end{array}$ & $\begin{array}{c}-0.312^{* * *} \\
(0.076)\end{array}$ & $\begin{array}{c}0.001 \\
(0.974)\end{array}$ & $\begin{array}{c}0.001 \\
(0.965)\end{array}$ & $\begin{array}{c}0.001 \\
(0.974)\end{array}$ & $\begin{array}{c}0.002 \\
(0.955)\end{array}$ & $\begin{array}{l}-0.018^{*} \\
(0.000)\end{array}$ & $\begin{array}{l}-0.020^{*} \\
(0.000)\end{array}$ & $\begin{array}{l}-0.018^{*} \\
(0.000)\end{array}$ & $\begin{array}{c}0.001 \\
(0.814)\end{array}$ \\
\hline$L A / T D$ & $\begin{array}{l}0.063^{*} \\
(0.000)\end{array}$ & $\begin{array}{l}0.063^{*} \\
(0.000)\end{array}$ & $\begin{array}{l}0.063^{*} \\
(0.000)\end{array}$ & $\begin{array}{l}0.063^{*} \\
(0.000)\end{array}$ & $\begin{array}{l}0.022^{*} \\
(0.000)\end{array}$ & $\begin{array}{l}0.022^{*} \\
(0.000)\end{array}$ & $\begin{array}{l}0.022^{*} \\
(0.000)\end{array}$ & $\begin{array}{l}0.022^{*} \\
(0.000)\end{array}$ & $\begin{array}{l}-0.0006 \\
(0.105)\end{array}$ & $\begin{array}{c}-0.000^{* * *} \\
(0.071)\end{array}$ & $\begin{array}{l}-0.0006 \\
(0.122)\end{array}$ & $\begin{array}{l}-0.003^{*} \\
(0.000)\end{array}$ \\
\hline$T L / T A$ & $\begin{array}{l}-0.887 \\
(0.285)\end{array}$ & $\begin{array}{l}-0.561 \\
(0.494)\end{array}$ & $\begin{array}{l}-0.802 \\
(0.331)\end{array}$ & $\begin{array}{l}-0.648 \\
(0.433)\end{array}$ & $\begin{array}{l}-1.164^{*} \\
(0.009)\end{array}$ & $\begin{array}{c}-1.099 * * \\
(0.013)\end{array}$ & $\begin{array}{c}-1.163^{*} \\
(0.009)\end{array}$ & $\begin{array}{c}-1.136^{* *} \\
(0.011)\end{array}$ & $\begin{array}{c}-0.129 * \\
(0.000)\end{array}$ & $\begin{array}{c}-0.124^{*} \\
(0.000)\end{array}$ & $\begin{array}{l}-0.124^{*} \\
(0.000)\end{array}$ & $\begin{array}{l}-0.378^{*} \\
(0.000)\end{array}$ \\
\hline$O B S / T A$ & $\begin{array}{c}0.021 \\
(0.565)\end{array}$ & $\begin{array}{c}0.022 \\
(0.548)\end{array}$ & $\begin{array}{c}0.018 \\
(0.607)\end{array}$ & $\begin{array}{c}0.020 \\
(0.580)\end{array}$ & $\begin{array}{c}0.010 \\
(0.673)\end{array}$ & $\begin{array}{c}0.011 \\
(0.638)\end{array}$ & $\begin{array}{c}0.010 \\
(0.681)\end{array}$ & $\begin{array}{c}0.011 \\
(0.638)\end{array}$ & $\begin{array}{l}-0.001 \\
(0.143)\end{array}$ & $\begin{array}{l}-0.001 \\
(0.169)\end{array}$ & $\begin{array}{l}-0.001 \\
(0.160)\end{array}$ & $\begin{array}{l}0.006^{*} \\
(0.000)\end{array}$ \\
\hline$i$ & $\begin{array}{l}-0.037^{*} \\
(0.002)\end{array}$ & $\begin{array}{l}-0.039 * \\
(0.003)\end{array}$ & $\begin{array}{l}-0.046^{*} \\
(0.004)\end{array}$ & $\begin{array}{c}-0.026 * * \\
(0.018) \\
\end{array}$ & $\begin{array}{c}-0.012 * * * \\
(0.095)\end{array}$ & $\begin{array}{l}-0.032^{*} \\
(0.005) \\
\end{array}$ & $\begin{array}{l}-0.016 \\
(0.164) \\
\end{array}$ & $\begin{array}{l}-0.011 \\
(0.115) \\
\end{array}$ & $\begin{array}{c}-0.00 * * * \\
(0.068)\end{array}$ & $\begin{array}{c}-0.0007^{* *} \\
(0.014) \\
\end{array}$ & $\begin{array}{r}-0.0006 \\
(0.344) \\
\end{array}$ & $\begin{array}{l}-0.0004 \\
(0.204) \\
\end{array}$ \\
\hline$L N G D P G$ & $\begin{array}{l}-1.090 \\
(0.560)\end{array}$ & $\begin{array}{l}-2.311 \\
(0.271)\end{array}$ & $\begin{array}{l}-2.305 \\
(0.272)\end{array}$ & $\begin{array}{l}-0.717 \\
(0.719)\end{array}$ & $\begin{array}{c}1.068 \\
(0.563)\end{array}$ & $\begin{array}{l}-1.057 \\
(0.609)\end{array}$ & $\begin{array}{c}0.724 \\
(0.714)\end{array}$ & $\begin{array}{c}0.896 \\
(0.650)\end{array}$ & $\begin{array}{c}-0.067^{*} \\
(0.000)\end{array}$ & $\begin{array}{l}-0.064^{*} \\
(0.000)\end{array}$ & $\begin{array}{l}-0.061^{*} \\
(0.006)\end{array}$ & $\begin{array}{l}-0.050^{*} \\
(0.000)\end{array}$ \\
\hline CR3 & $\begin{array}{c}-11.119 * * * \\
(0.065)\end{array}$ & & & & $\begin{array}{l}-2.165 \\
(0.686)\end{array}$ & & & & $\begin{array}{c}0.013 \\
(0.897)\end{array}$ & & & \\
\hline CR5 & & $\begin{array}{c}-15.079 * * * \\
(0.093)\end{array}$ & & & & $\begin{array}{c}-20.53^{* *} \\
(0.022)\end{array}$ & & & & $\begin{array}{c}0.228 * * \\
(0.048)\end{array}$ & & \\
\hline HHI-Assets & & & $\begin{array}{c}-81.923 * * * \\
(0.095)\end{array}$ & & & & $\begin{array}{c}-21.366 \\
(0.640) \\
\end{array}$ & & & & $\begin{array}{c}0.671 \\
(0.438) \\
\end{array}$ & \\
\hline$H$-statistics & & & & $\begin{array}{c}0.057 \\
(0.886)\end{array}$ & & & & $\begin{array}{l}-0.090 \\
(0.814)\end{array}$ & & & & $\begin{array}{c}-0.014 * \\
(0.001)\end{array}$ \\
\hline No.of obs & 259 & 259 & 259 & 259 & 259 & 259 & 259 & 259 & 179 & 179 & 179 & 179 \\
\hline F-statistic & $6.672^{*}$ & $6.435^{*}$ & $6.628^{*}$ & $6.447^{*}$ & & & & & & & & \\
\hline Hausman test & & & & & $173.4^{*}$ & $167.2^{*}$ & $171.8^{*}$ & $167.5^{*}$ & & & & \\
\hline$R$-Squared & 0.568 & 0.567 & 0.567 & 0.562 & 0.236 & 0.246 & 0.237 & 0.236 & & & & \\
\hline $\begin{array}{l}\text { Hansen ( } p \text { - } \\
\text { value) }\end{array}$ & & & & & & & & & 0.475 & 0.432 & 0.441 & 0.496 \\
\hline$A R(2)$ & & & & & & & & & 0.128 & 0.113 & 0.134 & 0.271 \\
\hline
\end{tabular}

Note: ${ }^{* * *}$ and $* * *$ denotes statistical significance at the $1 \%, 5 \%$ and $10 \%$ level, respectively. 
Appendix 4: Estimation Results: Competition and Bank Risk Taking

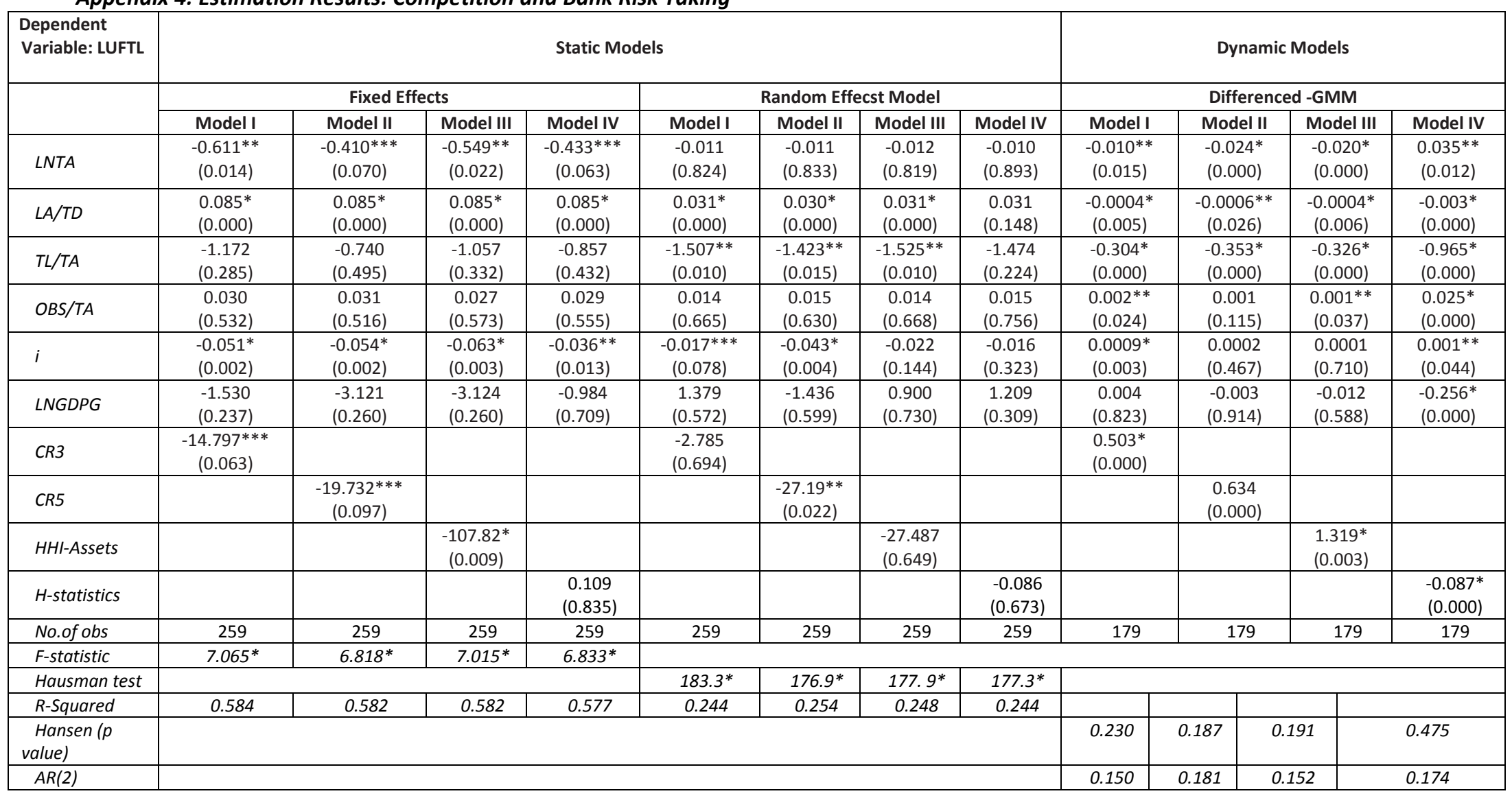

Note: ${ }^{* * *}$ and $* * *$ denotes statistical significance at the $1 \%, 5 \%$ and $10 \%$ level, respectively. 